\title{
Annual Report 2004
}
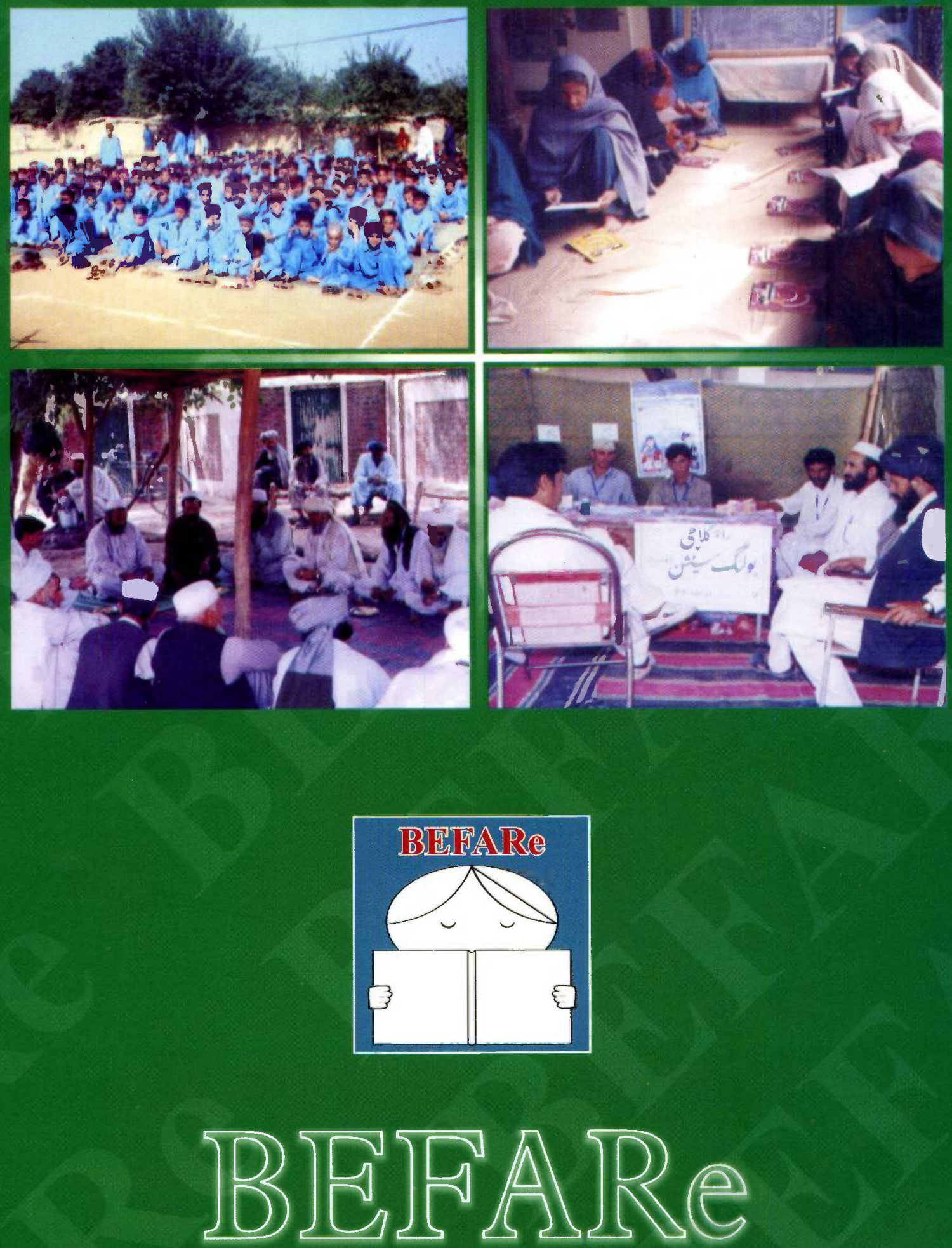
Prepared \& Compiled by: Fayyaz Ali Khan, BEFARe. Edited by: S. J. Shah, BEFARe.

Printed \& Designed by: Al-Azeem, Peshawar, Pakistan. 


\section{Annual Report}

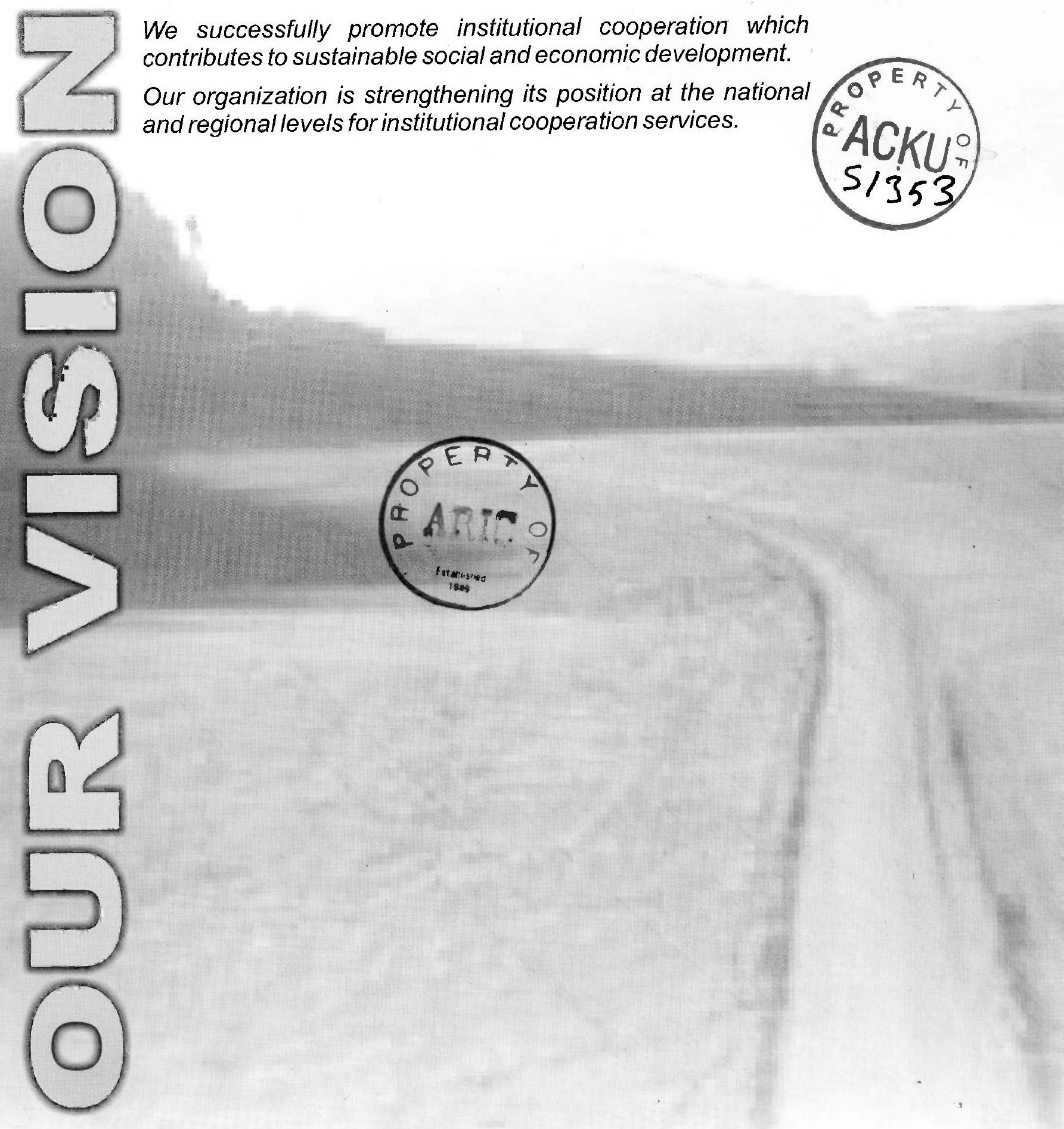



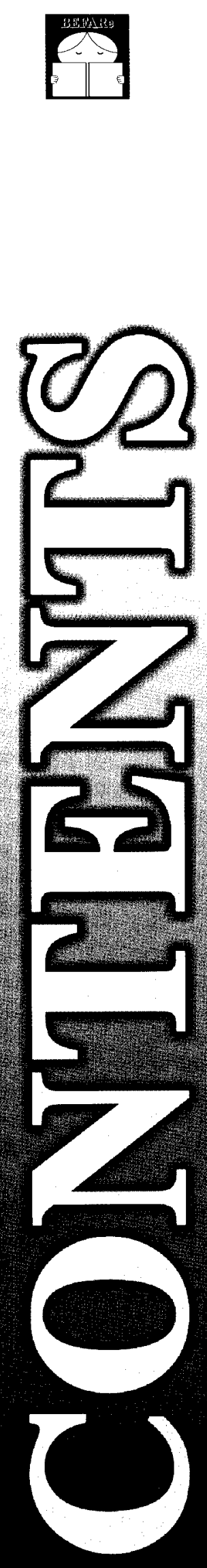

\section{CONTENTS}

MESSAGE FROM THE CHIEF EXECUTIVE

AREAS OF OPERATION AND SUPPORT

MISSION STATEMENT

PROJECT ACTIVITIES IN IMPLEMENTING 09 DEPARTMENTS

FORMALEDUCATION (FE)

NON-FORMAL EDUCATION (NFE)

COMMUNITY PARTICIPATION AND DEVELOPMENT (CP\&D)

RESEARCH AND DEVELOPMENT (R\&D)

TRAININGS SUPPORTED BY CANADIAN INTERNATIONAL DEVELOPMENT AGENCY

TEACHER TRAININGS SUPPORTED BY WORLD BANK

FACILITATING THE OUT-OF-COUNTRYREGISTRATION AND VOTING FOR AFGHAN PRESIDENTIAL ELECTION, SUPPORTED BY INTERNATIONAL ORGANIZATION FOR MIGRATION

POVERTY ALLEVIATION INITIATIVES SUPPORTED BYWORLD VISION 


\section{MESSAGE FROM THE CHIEF EXECUTIVE}

The year 2004 saw BEFARe changing its status from a bilateral project working for education of Afghan refugees to an independent entity with a wider scope of activities. Basic Education for Afghan Refugees; BEFARe (formerly GTZ-BEFARe) was established in 1990 under the terms of a bi-lateral agreement between the governments of Islamic Republic of Pakistan and Federal Republic of Germany to provide basic education including implementation of various developmental interventions on behalf of donors, partners and stake holders. In 2004, BEFARe transformed itself to cover wider scope of activitios for both Afghan refugees and local communities.

BEFARe apart from its committed responsibilities in basic education in 2004 continued to implement, on behalf of UNHCR, the largest refugee education sub-project in the world. BEFARe has successively implemented sub-projects for World Bank, UNESCO, UNICEF, the Department for International Development (DFID) of the British government and other international agencies. It continued to implement the CIDANAREP and achieved all its targets for the project year.

After transformation this year, BEFARe has been able to continue implementing sub-projects and engage additional donors for both Afghans and local communities. It also facilitated the Out-ofCountry Registration and Voting (OCRV) process for organizing the Afghan Presidential Election in NWFP on behalf of IOM.

As a part of its plans to work for local communities, BEFARe was able to initiate integrated adult literacy and vocational skills training courses in NWFP and Punjab. It was also able to develop a complete curriculum for out of school children, which can be implemented in near future. These initiatives are part of a comprehensive plan for local communities.

Furthermore, BEFARe was also able to successfully implement a programme aimed at poverty alleviation with the support of World Vision, Pakistan. BEFARe also signed a project cooperation agreement with the European Commission to implement a training programme for female local government councilors in NWFP and Punjab provinces.

Another notable achievement was the ISO 9001: 2000 certification. BEFARe initiated the installation process of a Total Quality Management System (TQMS) at its Head Office in Peshawar. Continuous commitment of the BEFARe team led to ISO 9001: 2000 certification of its Head Office by Moody's International.

It was strongly felt that the BEFARe experiences in refugee education as well as its successful transformation from a project to an independent organization be documented so that other organizations are also able to learn and benefit. For this purpose an international consultant Mr. Atle Hetland supported by GTZ, has been engaged, who is working on writing a book on the "History of BEFARe". This project is expected to be completed next year.

With these and other notable achievements, the Annual Report 2004 aims to share achievements and impacts of current sub-projects and takes stock of plans in the near future.

\section{Shakir Ishaq}

Chief Executive 


\section{Donor's Contribution}
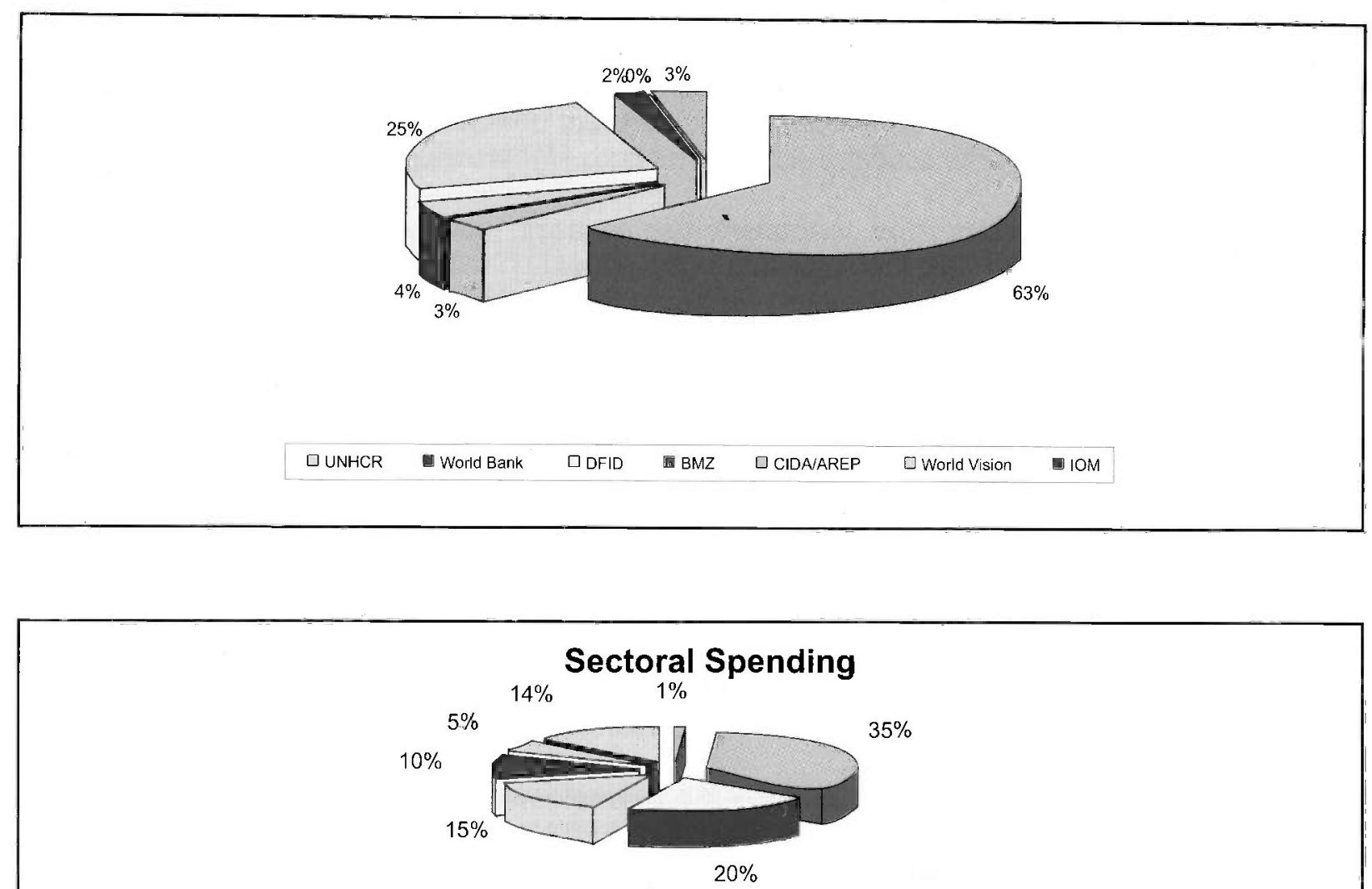

Democracy

Don-Formal Education

Training

图 Vocational Training (enterprise development)
Formal Education

ㅁ Health Education

Poverty Alleviation

BEFARe appreciates the support of the international community that ensured the achievement and success of our work. Funding from the following donors facilitated BEFARe to provide a variety of vital programs and assistance to the target community in 2004:

- United Nations High Commission for Refugees (UNHCR)

- World Bank

- Department for International Development (DFID)

- Canadian International Development Agency (CIDA)

- German Federal Ministry for Economic Co-operation and Development (BMZ)

- World Vision

- International Organization for Migration (IOM) 


\section{BEFARe in 2004}

According to estimates, though a large number of Afghan refugees still reside in camps and urban areas of NWFP; there has been a gradual increase in repatriation trends. Nonetheless, the caseload of students with BEFARe largely remained static. The yearly enrollment in the formal education schools funded by UNHCR reached 99,451 students in the last quarter of the year $[72,977(73 \%)$ were boys and $26,474(27 \%)$ were girl students] as against 95,454 students $[70,939$ were boys and 24,515 were girl students] who appeared in the final examinations in April 2004.

Under the Non-Formal Education, the total number of participants in the reporting year reached 6,886 . A total of 2,273 of these participants were males, while 4,613 were females in both home schools and the literacy programme through 399 integrated NFE courses.

BEFARe continued to implement the CIDANAREP which is aimed at training the Afghan refugees teachers and qualified indivduals. The programme is having an enormous impact as more and more refugees are registering to particiapate in the training seminars.

The intervention under the World Bank component continued to support teacher training and administration of courses in the formal and non-formal education. This, the 2nd phase of implementation included teacher training of BEFARe remote area schools, Middle and Secondary school of the CAR, and Self-help schools in the Formal Education.

With a wider and enhanced scope after transformation, BEFARe planned and initiated courses for Pakistani communities. BEFARe, in collaboration with Literate Pakistan organized trainings for its Master Trainers to equip them in teaching of basic competencies for adult literacy programmes for Pakistani communities. Later, integrated literacy and vocational skills training courses were initiated for Pakistani communities.

The Presidential Election in Afghanistan was organized in 2004. In this connection, the International Organization for Migration, (IOM) and BEFARe teamed-up to facilitate the Out-ofCountry Registration and Voting (OCRV) process for Afghan refugees in the NWFP. The process was a success as a large number of Afghan Refugees came out to vote. All BEFARe Sub-Offices located in these areas are coordinating activities at that level.

BEFARe was also successful in implementing a programme aimed at poverty alleviation through sustainable approaches. The programme supported by World Vision Pakistan distributed livestock in identified underprivileged Afghan and local host communities.

BEFARe signed an MOU with NRC under which NRC provided training to Master Trainers (MTs,) Field Education Supervisors (FESs) and School Teachers of BEFARe. The topics included peace education, conflict resolution, Dari Model lesson and teaching languages according to the new Afghan curriculum.

\section{S. J. Shah}

Divisional Manager

Programming \& Implementation Division 


\section{Mission Statement}

"BEFARe provides basic education on the national and regional level to the identified vulnerable and disadvantaged groups. This is achieved and ensured through learner centered and activity based approaches. BEFARe continuously reviews and updates its

\section{Our Goal}

"To improve and contribute towards better living standards of the identified displaced and underprivileged communities through interventions such as quality education, vocational \& skills training, health, sanitation, micro-finance, enterprise development, innovative concepts, methodologies, quality teaching and learning material, including its technical and professional capacity. Our aim is to encourage involvement, participation, partnership and empowerment to and with all stakeholders."

poverty alleviation and socio-economic development initiatives."

The organization fulfilled its obligations under the following well-defined and proactive structure:-

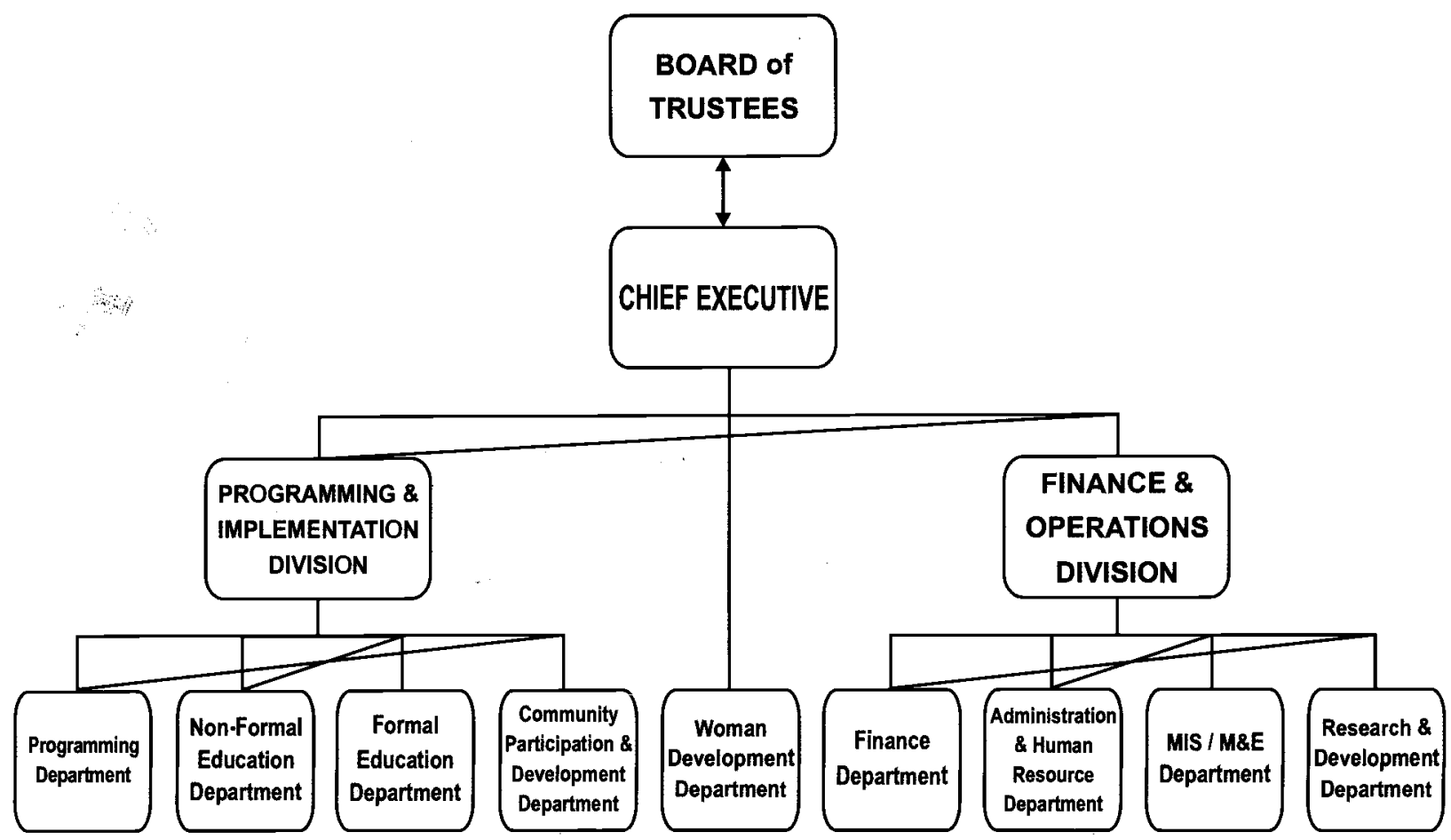




\section{PROJECT ACTIVITIES IN \\ IMPLEMENTING DEPARTMENTS}

\section{Formal Education (FE)}

BEFARe, in 2004, continued to manage 259 (65 girl schools, 156 boy schools and 38 coeducation) schools through its six sub-offices. It continued to successfully implement the COPE sub-project in its $9^{\text {th }}$ year of implementation. Regular on-the-job training and comprehensive training seminars on regular basis for the teachers were organized. The pedagogical and administrative monitoring of the schools also continued as an ongoing activity during the year. Necessary supplementary material like books, note books and stationery etc. were provided to schools and teacher training seminars organized in all the sub-offices in NWFP.

All planned targets pertaining to Formal Education (FE) Department were achieved under the UNHCR, World Bank, and CIDAAREP components. The project, in pursuance of its quality goals engaged experts to facilitate quality training to Master Trainers and field staff in implementation and management of schools and facilities. Subsequently, the contents of these trainings were cascaded to the teachers in schools through further training workshops.

Objectives for the Year 2004 for UNHCR sub-project

The department pursued the following objectives for the academic year 2004:

- Administration and maintenance of all the schools under its implementation.

- Regular monitoring of schools for improved quality education with active community participation.

- $\quad$ Increased use of multi-grade teaching at schools where there was shortage of teachers.

- Voluntary teachers training seminars by the Field Education Supervisors.

- $\quad$ Extensive collaboration with UNHCR and other implementing partners for smooth implementation processes.
- Upgrading the school physical environment with community participation.

- Regular and timely distribution of books, stationery and materials.

- $\quad$ Organizing extra curricular activities for the students with the help of parents and community.

- $\quad$ Participation of the community through the SMCs in decision-making and proportional implementation process.

- Participation of the community in the collection of funds, repair / maintenance and white-wash of schools, tree plantation, organizing of extra curricular activities of students and other school related activities.

The organization continued to put more emphasis on further strengthening of its educational approach and methodology with more accountable and transparent implementation process to contribute to the overall policy objective of UNHCR of moving gradually towards refugee ownership of the educational services such as in:

Repair of classrooms.

- Active involvement of community in environmental and health awareness interventions.

- Appointment of additional teachers.

- Monitoring of teacher's attendance.

- Demand and distribution of educational material.

- $\quad$ Fund raising and its bookkeeping

- Control in student drop out (especially among girl students).

- School administration and quality control.

\section{Annual Examinations and Result Analysis}

The annual examinations were held in March which were regularly monitored by the staff deputed at Sub Offices as well as by the teams 
constituted from the Main Office. In the session (2004), 95,454 students comprising of 70,939 nts comprising of 65,999 (93\%) boys and $22,171(90 \%)$ girls passed the examination. Among the Sub Offices, Mardan led the list with an overall pass percentage of $95 \%$ followed by Hangu and Bannu with an overall figure of $94 \%$. The organization experienced an overall pass percentage of $92 \%$ during the reporting year.

Table 1: Annual Examination Result Analysis in 2004

\begin{tabular}{|c|c|c|c|c|c|c|c|c|c|c|c|c|}
\hline \multirow{2}{*}{ Sub-Offices } & \multicolumn{3}{|c|}{ Appeared } & \multicolumn{3}{|c|}{ Passed } & \multicolumn{3}{|c|}{ Failed } & \multicolumn{3}{|c|}{ Pass $\%$ ages } \\
\hline & Boys & Girls & Total & Boys & Girls & Total & Boys & Girls & Total & Overall & Boys & Girls \\
\hline Abbottabad & 14,041 & 3,181 & 17,222 & 12,929 & 2,918 & 15,847 & 1,112 & 263 & 1,451 & 92 & 92 & 92 \\
\hline Bannu & 6,318 & 1,336 & 7,654 & 5,953 & 1,247 & 7,200 & 365 & 89 & 411 & 94 & 94 & 93 \\
\hline Hangu & 11,901 & 2,244 & 14,145 & 11,165 & 2,118 & 13,283 & 736 & 126 & 922 & 94 & 94 & 94 \\
\hline Mardan & 10,893 & 3,999 & 14,892 & 10,339 & 3,809 & 14,148 & 554 & 190 & 736 & 95 & 95 & 95 \\
\hline Peshawar & 20,433 & 7,457 & 27,890 & 18,917 & 6,409 & 25.326 & 1,516 & 1.048 & 2,330 & 91 & 93 & 86 \\
\hline Timergara & 7,353 & 6,298 & 13,651 & 6.696 & 5,670 & 12,366 & 657 & 628 & 1235 & 91 & 91 & 90 \\
\hline Total 2003-04 & 70,939 & 24,515 & 95,454 & 65,999 & 22,171 & 88,170 & 4,940 & 2,344 & 7,284 & 92 & 93 & 90 \\
\hline
\end{tabular}

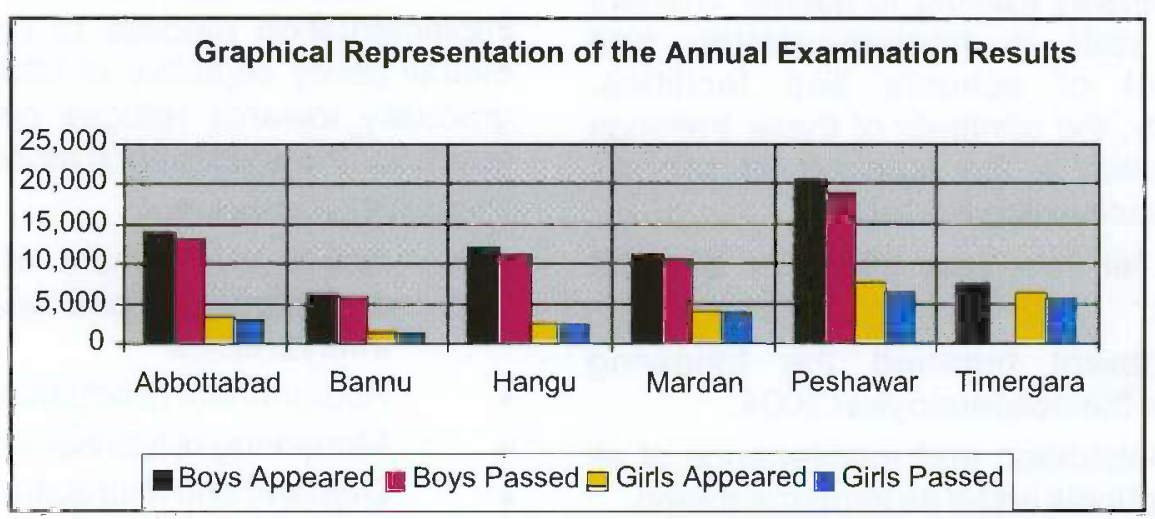

\section{Recollection of Books}

BEFARe continued to make use of re-usable books. During the reporting period, the organization collected 98,238 old useable books from the students and utilized the same books, in addition to the provision of new books. For details of the recollected books, please see Annexure $1 \& 2$. 


\section{Non-Formal Education (NFE)}

The Non-Formal Education (NFE) department continued to offer basic education in the fields of adult literacy with integrated Mother Child Health $(\mathrm{MCH})$ course being offered only to the female participants of the literacy programme; and adult literacy integrated with vocational education and skills training for males. The department also continued its Home School (HS) courses for both boys and girls in identified areas.

The commitments under the World Bank component for NFE continued in 2004 for their implementation. Additionally, 2004 saw CIDAIAREP contribute to the home schools and adult literacy programmes of NFE. These interventions greatly assisted reaching those areas and target communities, which were either neglected because of scarcity of funds or not reached on account of logistical problems. Sustained efforts were also made to reach out to Afghan women and vulnerable persons in remote areas with these interventions. These are discussed in further detail under the adult literacy and home schools activities.

In the reporting year, the total number of Afghan refugee participants in the project year reached to around 6,886 . A total of 2,273 of these were males while 4,613 were females in both home schools and literacy programme through 329 NFE courses. The NFE department continued to implement courses in adult literacy, integrated with mother and child health education and home schools to achieve the following goals: -

- $\quad$ Maintain, expand and augment quality of the already operational NFE courses on sustained basis in the selected refugee camps and local communities.

- Expansion and implementation of the experiences gained through courses in remote and inaccessible areas.

- $\quad$ Training of NFE teachers for improved and revised methodologies.

Refresher tutorials/seminars for all teachers. monitoring and supervision of teachers and provision of timely feedback to those in need.

- Mid and final testing of all participants.

- $\quad$ Exposure of Master Trainers (MTs) to issues like gender and drug abuse etc.

- Training of staff members of other agencies.

The department has also brought in a marked improvement in awareness trends of the target community regarding health related issues like:

- Infant mortality

- Infertility

- Diet and hygiene

- Danger signs in pregnancy

- $\quad$ Procedure for a safe and healthy child birth

- $\quad$ Breast feeding

- Vaccination

- Mine awareness

- Drug abuse etc.

The department continued with its special emphasis on further improving its pedagogical outputs by providing regular on-the-job training and coaching to its teaching staff. Basic and refresher trainings were provided to the teachers of home schools and literacy courses which covered the following:

- $\quad$ Pre-reading concepts

- $\quad$ Structure of the teacher guide

- $\quad$ Analysis of lesson plan

- Home school class and literacy course organization

- $\quad$ Teaching aids and its development from locally available material

- $\quad$ Understanding the child and the adult participant

- $\quad$ Problem based teaching, positive and negative learning, taxonomy, group 
work and its advantages, home work, its checking procedures/methods.

\section{a) Adult Literacy (male and female)}

The Adult Literacy courses engaged those adults who could not acquire basic education at earlier stages of their lives. The programme directly contributed to human development capacities of adult groups and augmented towards improved family situations. This programme facilitated attainment of skills like reading, writing, and simple calculations etc. The duration of the literacy course is 18 months, divided into three levels (Primer, Arithmetic and Reader) of six months each. During the year 2004, a total of $2,405(1,750$ females) participants acquired literacy skills through a total of 120 literacy courses under the World Bank and CIDA/AREP components. Detail of courses and participants may be cited in Annexure 4, 5, 6, 7 \& 8 .

\section{B) Home Schools (girls and boys)}

Home School courses are intended for those boys and girls who, for a various reasons, cannot or could not go to schools. These schools are run in those areas where there are no schools available or schools are at a distance and not easily accessible. This accelerated programme of 30 months covering 5 grades of formal school curriculum serves as a bridge between FE and NFE for those girls and boys who want to continue their education in the formal schools.

Under the CIDA/AREP component, 3,311 participants graduated from 146 home schools courses. Among which 2,358 were females and 1,057 were male students. Furthermore, 870 (400 girls) participants graduated from 33 coeducation home school courses. A detailed review of statistics can be cited in Annexures 3 , $4,5,6,87$.

The Mobile Library programme was continually benefited from by the teachers and participants in the NFE programmes. These are introduced to fulfill the needs of those home based schools and literacy courses, especially where there was a lack of such facility at the camp and community level.

The NFE department also initiated Vocational Skills Training courses in Peshawar, Timergara Abbottabad and Mardan and Hangu for males and females. Around 300, with 205 female participants gained vocational skills in tailoring, embroidery, beads-making. The 95 male participants gained skills in tailoring, carpentry and bicycle repair. (See detail in annexures 8 \& 9).

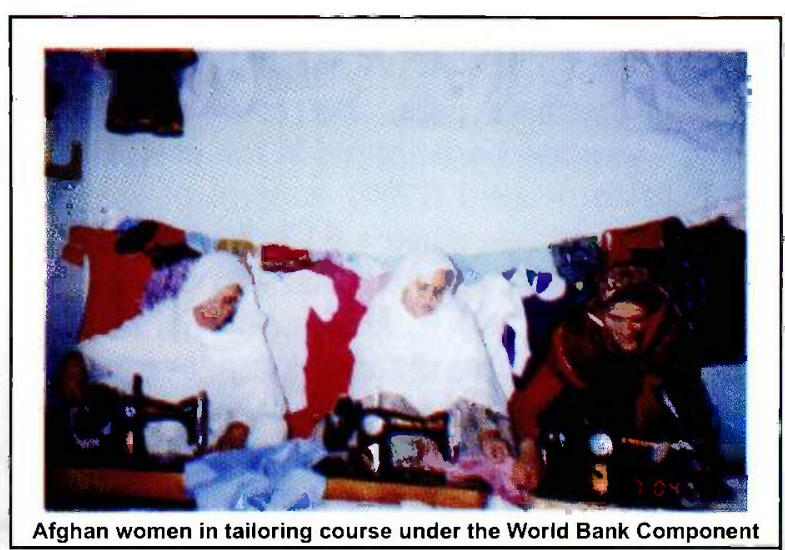

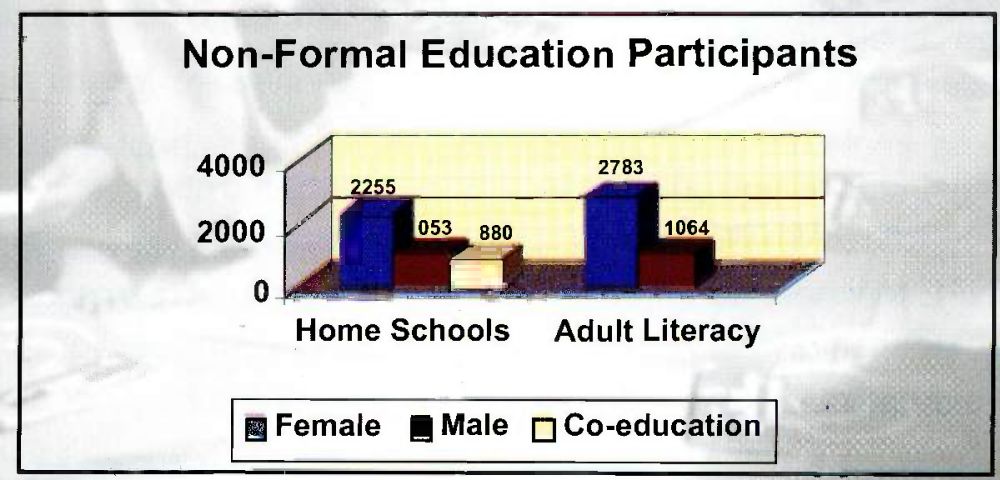


Later, a display to sell and market some of the products at the main office level was also organized.

\section{Programmes for local communities}

Entering 2004, with a wider and enhanced scope, the NFE initiated a training programme in context of BEFARe's plans to initiate Courses for Pakistani Communities. It was essential that the Master Trainers at BEFARe are well equipped to initiate teacher trainings at various identified locations. BEFARe, with the collaboration of Literate Pakistan organized trainings for its Master Trainers to equip them in teaching of basic competencies for adult literacy programmes for Pakistani communities.

The Master Trainers, subsequently, organized training programmes teachers and helped them initiate integrated adult literacy and vocational skills training courses in identified areas in Baffa-Manshera, Swabi and Attock. More than 350 participants graduated from around 20 courses. Similarly, more than 50 participants in Baffa and Attock were also imparted vocational skills training courses in tailoring.

Inline with its future plans for local host communities, BEFARe also plans to implement progammes for out-of-schools children. A separate curriculum in that context has been also developed.

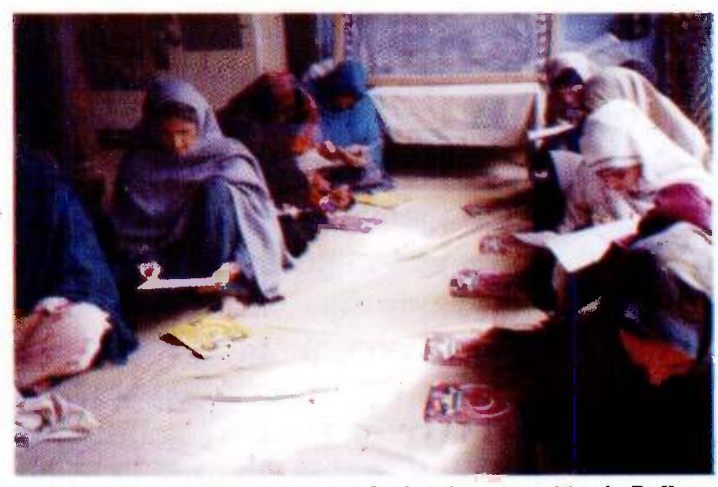

A female adult literacy course for local communities in Baffa 


\section{Community Participation and Development (CP\&D)}

The recent developments in Afghan refugee situation required the Community Participation and Development (CP\&D) Department to select a wider and more proactive role as far as motivating the refugee community is concerned.

The department, in addition to its assigned responsibilities, was extensively utilized in the Out-of-Country Registration and Voting (OCRV) for Afghan refugees. Besides, it continued to successfully motivate the refugee communities for self reliance and sustainable development in the provision of education particularly to Afghan females.

The department sustained close contact with the community and facilitated extra curricular activities for students with active and coordinated involvement of school staff, parents and community. It continued to strive to motivate community to support schools and teachers identified for retrenchment at the end of the year

It employed workable approaches in the field by mobilizing resources to yield positive results through community involvement. The department relentlessly organized SMC trainings and reorganizations where required. More emphasis was put on motivating refugees to take proportional responsibilities of schools and teachers by proactive involvement and by way of financial contribution.

Through the School Management Committees (SMCs), the Afghan refugee communities were able to comprehend that they themselves will have to play their roles in the implementation of

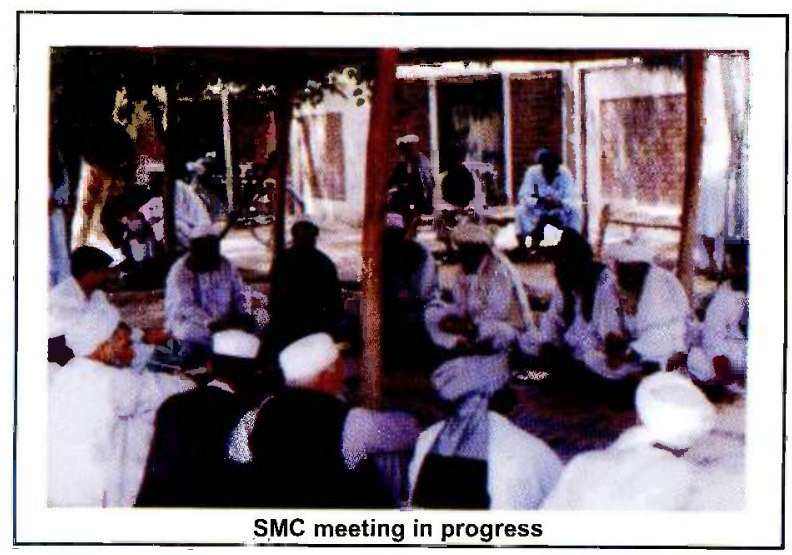

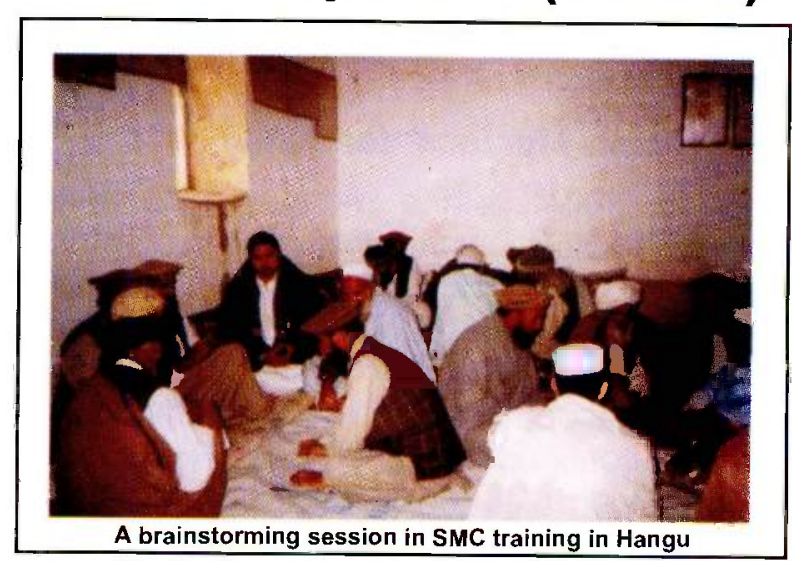

programmes through voluntary and selfdetermined participation. The SMCs were successfully engaged to voluntarily assist the school management in affairs related to education in identified schools. The community was effectively motivated for active involvement in the school / education related issues such as: conflict resolution between school and community; step up physical and learning environment in the school; check and controlling the dropout of the students including absenteeism; increase in enrollment (formal \& non-formal) education; organizing and contributing for arranging extra-curricular activities their children's encouragement; fund raising for school development and its appropriate utilization; maintenance of the schools buildings and infrastructures etc. The community also played its role in advising and recommending their view point for further enrichment in delivery of educational services.

During the year 2004, the department continued to encourage community participation and self-reliance in the target group through the SMCs trainings, follow-up meetings and visits by the Community Motivators. The SMCs were engaged in campaigning for awareness, controlling student's absenteeism and dropout, conflict resolution, fund raising for school development i.e. repair and maintenance, additional construction for improving the schools learning and physical environment and holding of 
monthly SMC meetings etc.

This year, a sum of more than Rs. 3.4 million was raised by the SMCs for the support of primary education throughout the operational areas. Detail of funds raised may be cited in Annexure 10.

A total of 38 classrooms, 35 verandas, 170 roof replacements, 23 toilets, and 43 wells diggings were carried-out with the funds collected through the community.

The SMCs continued to contribute to repair and maintenance of schools buildings and 170 schools were white washed and 143 schools were either mud plastered or repaired. Detail of these activities may be cited in Annexure 11, \& 12.

Table 2: SMC's Training in the Year 2004

\begin{tabular}{|l|c|c|}
\hline \multirow{2}{*}{ Sub-Offices } & \multicolumn{2}{|c|}{ SMCs received Refresher Training } \\
\cline { 2 - 3 } & $\begin{array}{c}\text { No. of Refresher } \\
\text { Trainings }\end{array}$ & Members \\
\hline Bannu & 5 & 55 \\
\hline Peshawar & 15 & 132 \\
\hline Mardan & 6 & 68 \\
\hline Hangu & 9 & 118 \\
\hline Timergara & 7 & 86 \\
\hline Female & 8 & 120 \\
\hline Total & 50 & 579 \\
\hline
\end{tabular}
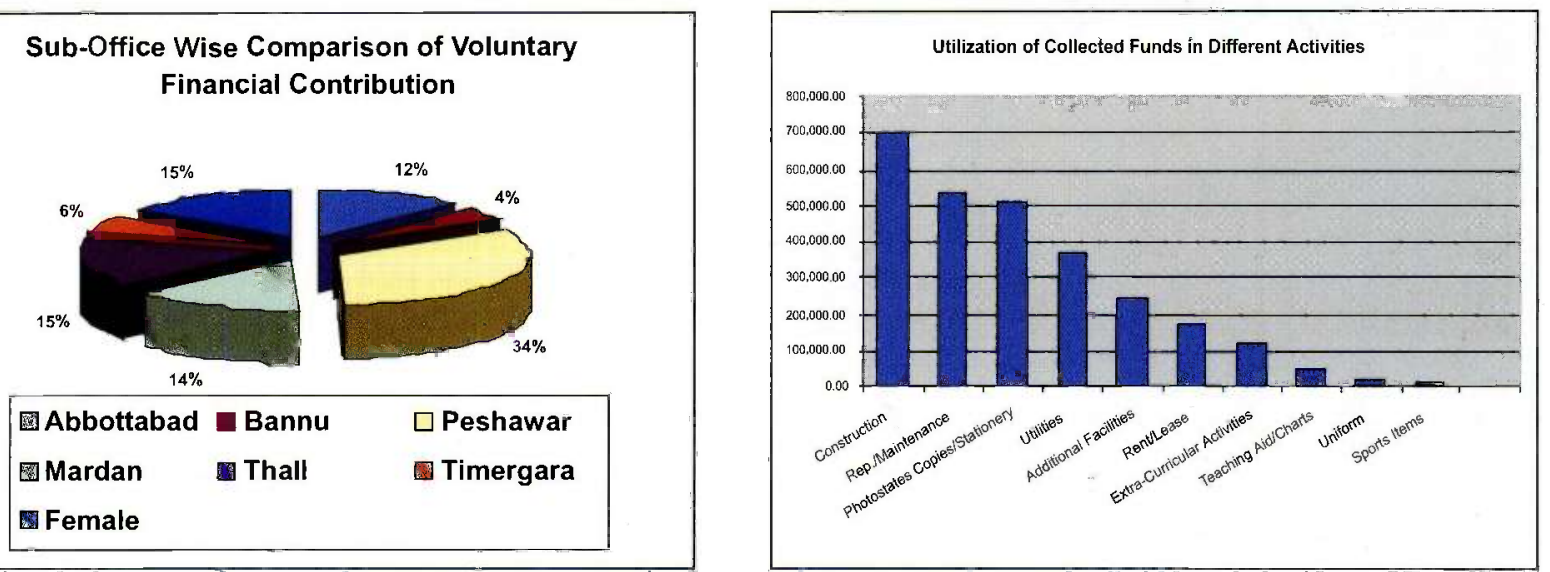


\section{Co-Curricular Activities}

At BEFARe co-curricular activities integration in the educational programme is considered an important part for mental and physical development of the child. These activities remarkably help in improving child behavior, talents, development of self-confidence, and decision making power. The CP\&D department

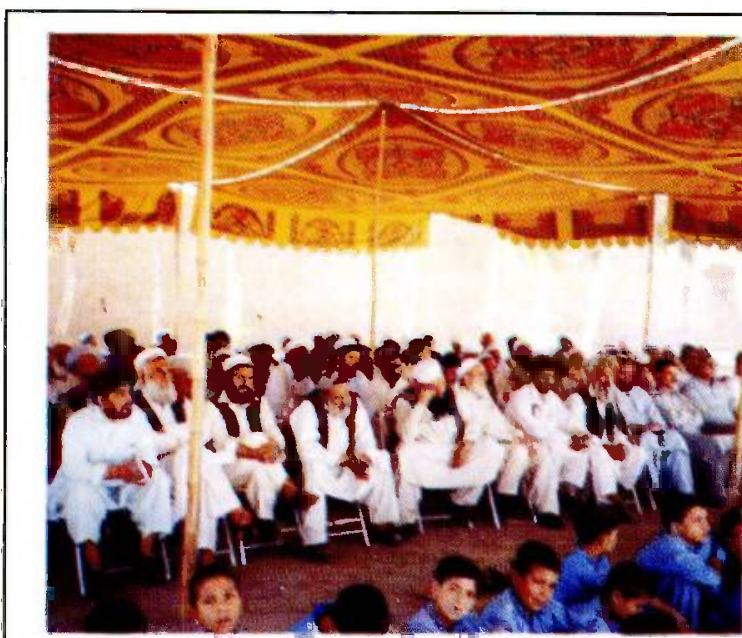

Grand Community Meeting organised by CP\&D deptt: in refugee Camp

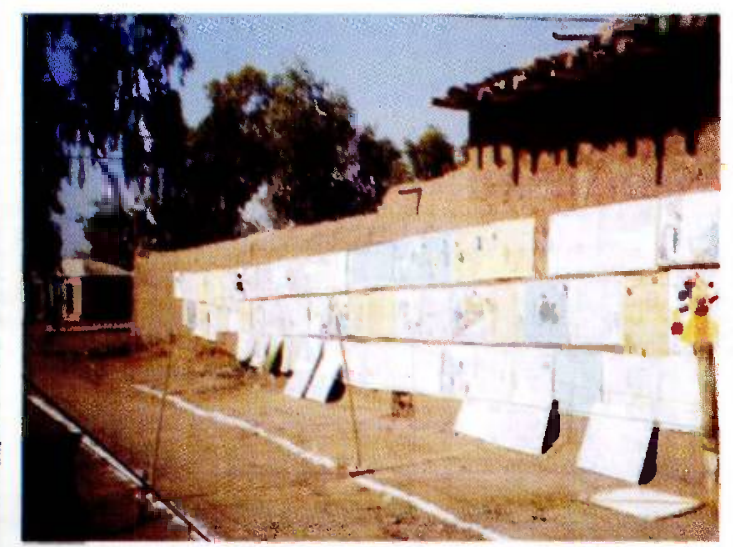

Poster Competition at the Grand Community Meeting in refugee Camp

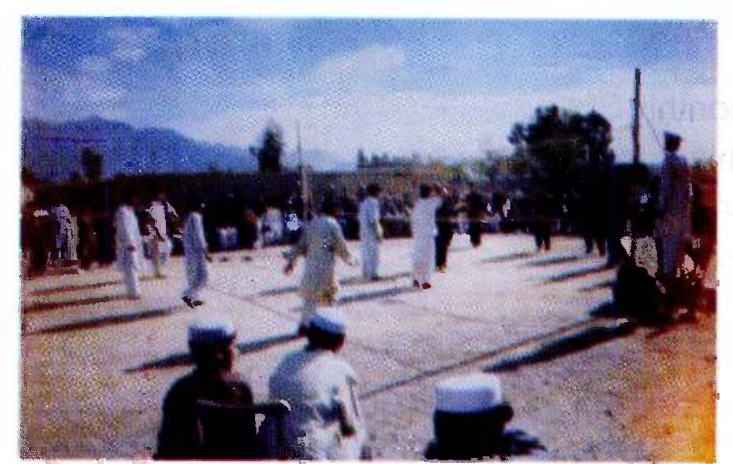

A Volley ball match depicting the sports activities

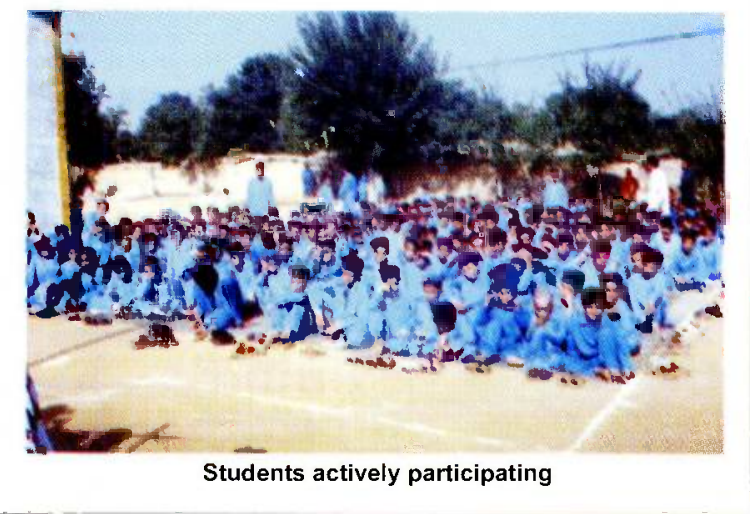

continued to facilitate the schools and community in organizing sports, debating, and poster competitions through organizing annual, parent days and internationally noted days like world health day, women rights day and international literacy day.

Details of these activities may be cited in Annexure 13, 14, \& 15 . 


\section{Research and Development (R\&D) Department}

Research and Development has been vital in provision of technical support to all implementation activities. It aims at producing; revising and developing object oriented teaching learning materials based on the daily needs of the target groups. These are complemented closely by related teacher guides and teaching aids with learner centered approaches.

The department also develops functional and job oriented basic education and training materials for Afghan refugees (children, adult, male, female) in conflict and relief situations, so that they develop their knowledge, attitude, skills to be able to cope with daily needs of life and are able to actively participate in reconstruction and development of Afghanistan.

\section{Curriculum Development for Out-of-School Children in Pakistan}

In context of plans for the local communities, the Research and Development (R\&D) Department has been engaged in development of curriculum for the out-ofschool children.

The Research and Development Department completed the set of books to be implemented in programmes for out-of-school children in Pakistan. The two and half year programme will enable children to enroll in Grade- 6 of the formal education system of Pakistan. Separate teacher training manuals are also being worked on, which will further augment towards the effective implementation \& quality of education for this progarmme.

Research Studies (Study on achievement levels based on concepts) diminishing pupil interest in classroom can be too much focus on the content rather than the concept. In refugee situation, the physical conditions of schools, the nature of curriculum, the qualifications of teachers, the teachers training programmes and many other pedagogical aspects, are quite different from the local schools.

As a follow-up of Evaluation Report of the UNHCR (2002), a study on "Concept Analysis in Pashto and Mathematics with Reference to Students' Achievement" was carried out by Dr. Mehmooda Rehman and Mr. Shah Agha Mujjadadi from BEFARe. The study is the first of its nature in Pakistan. It, among other things focuses on the level of achievement of refugee students in Pashto and Mathematics, classify the test items of the questions papers at various grades in accordance to different concepts, analyze the question papers according to the taxonomy of curriculum objectives and identify concepts which are difficult or easy to understand by students. It also identifies the significant differences, taking into consideration, gender, grade and geographical area. The study also makes recommendations in test construction, supervision, teaching, organizing training programmes and curriculum development. The report of the study was shared with UNHCR, UNICEF, CIDA/AREPand implementing partners including the IRC and Ockenden International (OI).
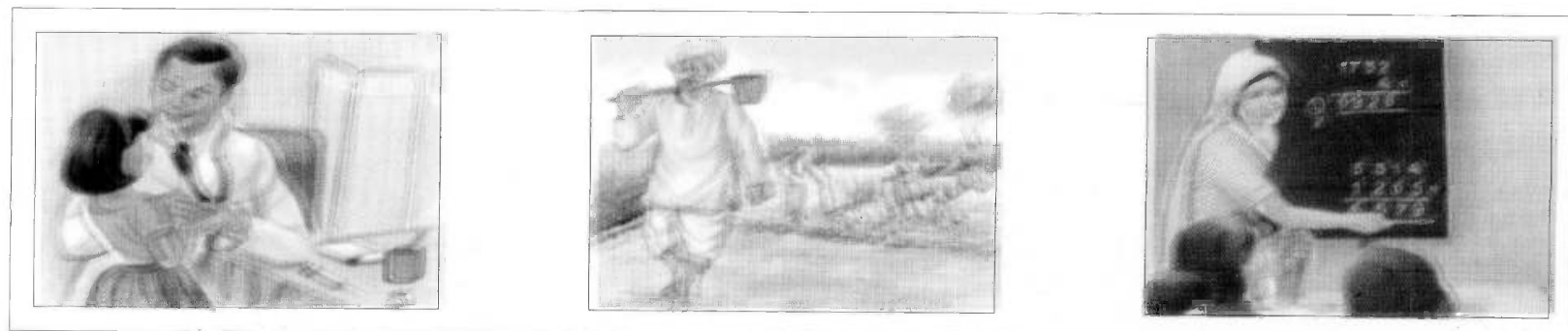

Pictures of some of listed professions in the newly developed Urdu text book by R\&D at BEFARe 


\section{Trainings supported by Canadian International Development Agency}

The Afghan Refugee Education Project (AREP) under CIDA is aimed at training and capacity building of more than 2,600 Afghan refugee teachers, trainers and field education supervisor. The aim behind the programme is to train Afghan teachers who after repatriation to Afghanistan would prove as a vital human resource for education interventions in Afghanistan and are able to contribute towards the formal and non-formal education systems. In the sub-project span of around three years, the intervention encompasses both in-service and pre-service i.e. individuals with little or no experience in teaching.

The specific objectives include:

1. Teachers of both formal and non formal sectors (second chance) are trained, through In-service training courses, to work with project material as well as non-project material on learner centered basis and child friendly methodology;

2. Potential candidates are trained as teachers through Pre-service training for capacity building and later employment in camps or in Afghanistan after repatriation;

3. Appropriate teaching, learning and life skills are provided to students of formal and home schools;
4. Teacher training course modules for successive teacher training courses are designed, tested and implemented.

BEFARe continuously revised and up-graded training contents for Master Trainers, Field Education Supervisors and teachers. In order to accomplish targets of female participation in the trainings, specific efforts were made to encourage increased female participation in these trainings. The pre-service trainings, largely organized in Peshawar, have been immensely popular, as a large number of young female Afghan graduates actively participated. As a recommended best practice, before initiation of the training a pre-test has always been administered to all the participants. The scores of each individual and group were analyzed for specific areas that needed particular attention. The contents were upgraded and revised as the demand required. Later, a post test was administered to analyze the improvements and shortcomings if any.

The project was initiated in April 2003 and till December it achieved all the targets planned for the year. In the formal education, the project succeeded in achieving the envisaged target of training the In-service teachers. In the Non-Formal Education too the project achieved all the training targets. Similarly, Master Trainers and Field Education Supervisors were also trained as envisaged. 
Table 4:Training of Teachers in under the CIDA/AREP 2004

\begin{tabular}{|c|c|c|c|c|c|c|c|c|}
\hline \multirow{3}{*}{ Field-Office } & \multicolumn{4}{|c|}{ Formal education } & \multirow{2}{*}{\multicolumn{2}{|c|}{$\begin{array}{l}\text { Non-Formal } \\
\text { Education }\end{array}$}} & \multirow{2}{*}{\multicolumn{2}{|c|}{ Grand Total }} \\
\hline & \multicolumn{2}{|c|}{$\begin{array}{c}\text { In-Service } \\
\text { Teachers }\end{array}$} & \multicolumn{2}{|c|}{$\begin{array}{c}\text { Pre-Service } \\
\text { Teachers }\end{array}$} & & & & \\
\hline & Male & Female & Male & Female & Male & Female & Male & Female \\
\hline Mardan & 17 & 32 & 0 & 0 & 0 & 0 & 17 & 32 \\
\hline Timergara & 8 & 46 & 39 & 0 & 93 & 60 & 140 & 106 \\
\hline Hangu & 29 & 19 & 0 & 0 & 58 & 0 & 87 & 19 \\
\hline Bannu & 32 & 5 & 0 & 0 & 0 & 0 & 32 & 5 \\
\hline Abbottabad & 7 & 33 & 58 & 17 & 61 & 44 & 126 & 94 \\
\hline Peshawar & 0 & 97 & 0 & 122 & 36 & 94 & 36 & 313 \\
\hline Total & \multicolumn{2}{|c|}{325} & \multicolumn{2}{|c|}{236} & \multicolumn{2}{|c|}{446} & \multicolumn{2}{|c|}{1,007} \\
\hline
\end{tabular}

The training contents of the Pre-Service teacher training comprised of conditions in learning, individual differences, teaching reading skills, characteristics of adult and child learner, teaching geometrical concepts, teaching methods, role of psychology in learning, making lessons plans, teaching science for grade- $V$, how negativism in learning can be directed to positivism, bias against women, assignment methods, prevention of HIVIAIDS, gender biases, evaluation, classroom organization and a host of many other latest concepts in education.

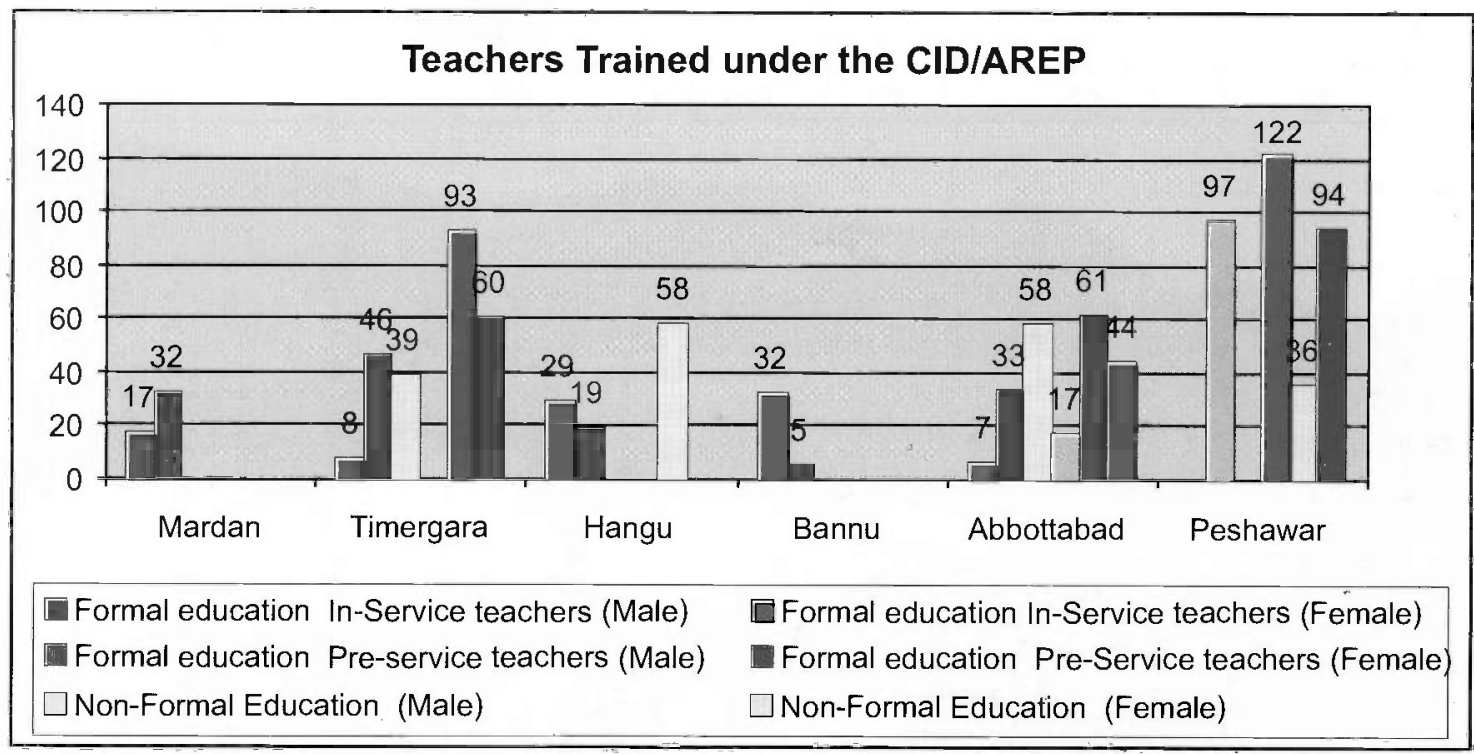

After repatriation, many of the teachers and trainers engaged with BEFARe and who have availed the CIDA/AREP trainings, have been engaged in well-paid positions in various notable organizations in Afghanistan. 


\section{Teacher Trainings supported by World Bank}

After the successful implementation of the $1^{\text {st }}$ phase, the $2^{\text {nd }}$ phase of the World Bank component was initiated in 2004. This phase comprised of teacher training support for remote area schools of BEFARe, Middle and Secondary schools of the CAR, Self-help schools and implementation of Non-Formal Education courses, provision of teacher training and initiation of vocational education and skills training in identified areas. All the objectives under this programme were achieved in the $1^{\text {st }}$ phase. Though on a smaller scale, the $2^{\text {nd }}$ phase was planned to further augment and enlarge scope of trainings.

A total of 67 teachers and head teachers were trained in these remote area schools, out of which 55 were male and 12 were female teachers. More than 4,000 students of remote area schools directly benefited from the interventions in the $2^{\text {nd }}$ phase. The participants were monitored in their classes and they were also regularly appraised for their needs and contents.

The training contents briefly comprised of prereading concepts, structure of the teacher guide, analysis of lesson plan, classroom organization, teaching aids and its development from locally available material, peace education, test and evaluation, problem based teaching, positive and negative learning, taxonomy, group work and its advantages and a host of other contents.

\section{Table 5: Training of Teachers in Remote Area Schools}

\begin{tabular}{|l|c|c|c|c|}
\hline Sub-office & $\begin{array}{c}\text { Total No. of } \\
\text { Schools }\end{array}$ & $\begin{array}{c}\text { Total Head } \\
\text { Teachers Trained }\end{array}$ & Male & Female \\
\hline Bannu & 15 & 33 & 29 & 4 \\
\hline Hangu & 17 & 34 & 26 & 8 \\
\hline Total & $\mathbf{3 2}$ & $\mathbf{6 7}$ & $\mathbf{5 5}$ & $\mathbf{1 2}$ \\
\hline
\end{tabular}
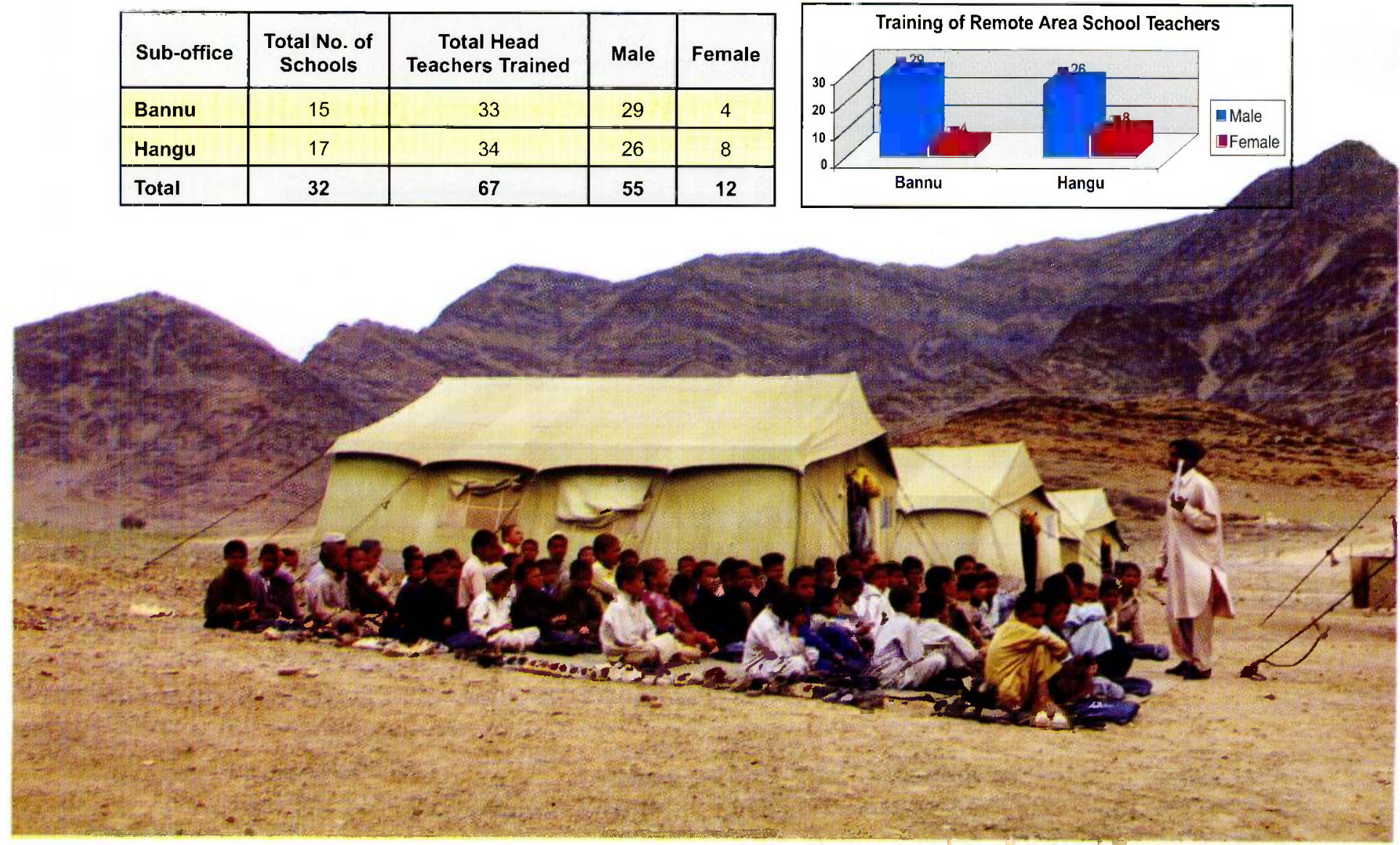
Identified teachers of Middle and Secondary Schools of the CAR were also trained in the $2^{\text {nd }}$ phase. A total of 134 middle and secondary schools teachers were trained. Females formed around $29 \%$ while males were $71 \%$ of the total participants.

Table 6: Training of Teachers of Middle and Secondary Schools

\begin{tabular}{|l|c|c|}
\hline \multicolumn{1}{|c|}{ Sub-office } & Male & Female \\
\hline Abbottabad/ Mansehra & 25 & 8 \\
\hline Mardan & 23 & 7 \\
\hline Peshawar & 8 & 17 \\
\hline Hangu & 15 & - \\
\hline Timergara & 24 & 7 \\
\hline Sub-Total & 95 & 39 \\
\hline
\end{tabular}

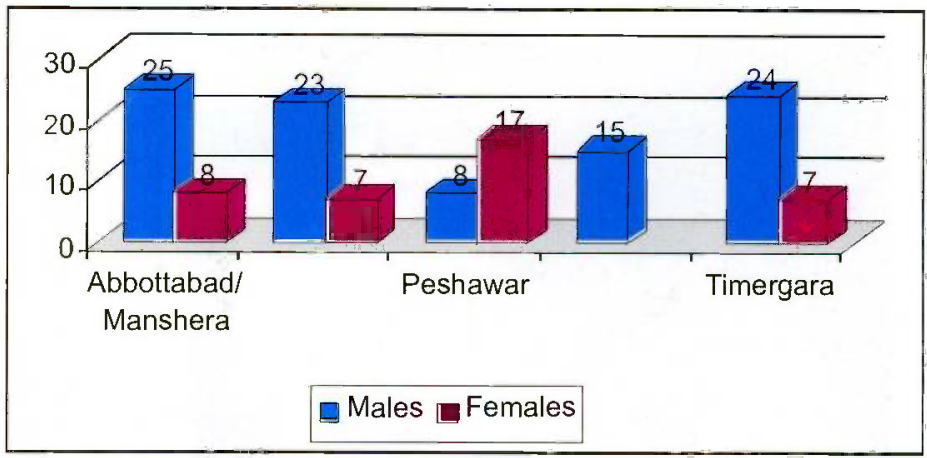

Furthermore, $\mathbf{2 0}$ teachers from identified selfhelp schools, who could not participate in the $1^{\text {st }}$ phase, were given quality training on various topics on latest techniques in teaching.
Mr. Habibullah Wajdi, the Education Specialist, from the World Bank office in Afghanistan, visited BEFARe, and visited schools related to the successful World Bank programme. The schools identified for the two-day visit were located in Peshawar and Hangu. Mr. Wajdi, visited Self-help, Middle and Secondary schools in Peshawar and Hangu. He also visited the Non-Formal Education courses in
Hangu. During his visit, he met the Afghan students, teachers and head teachers for their feedback on the World Bank supported trainings. He also went to the remote area schools located in the Orakzai Tribal Agency and vowed support for all efforts made by BEFARe for the educational development of Afghan Refugees.

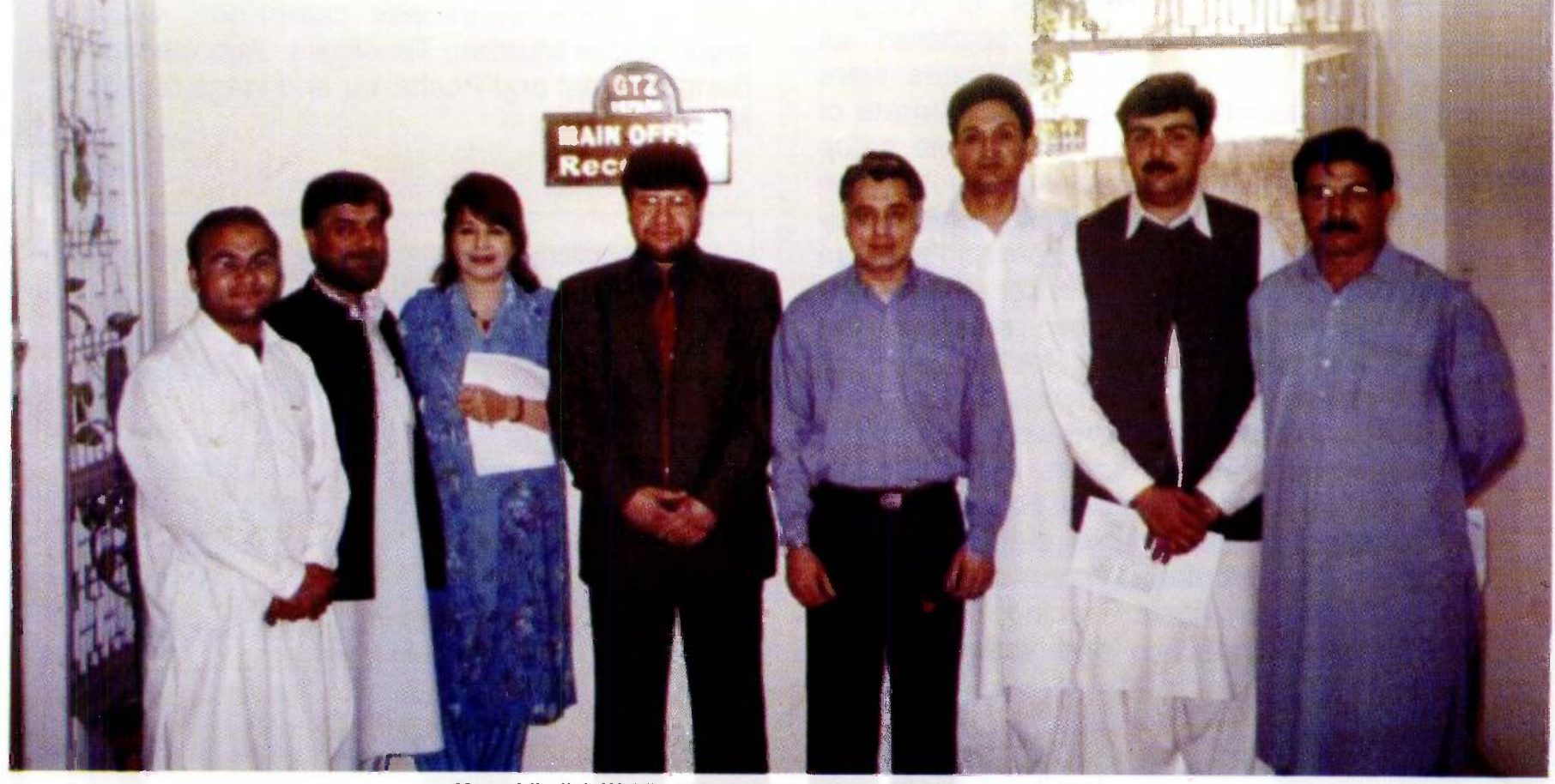




\section{Facilitating the Out-of-Country Registration and Voting (OCRV) for Afghan Presidential Election, Supported by International Organization for Migration}

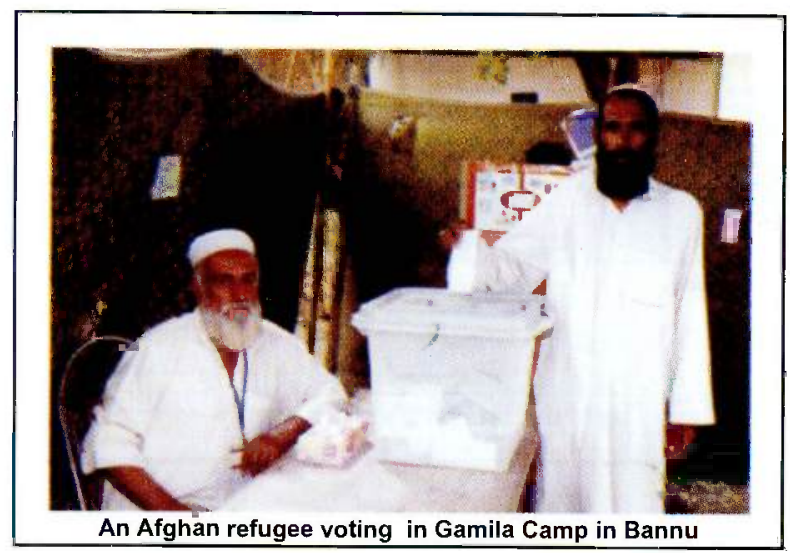

Afghanistan, a country ravaged by war and internal conflicts for more than two decades, had a chance to redeem itself in 2004. In October, presidential election were held. A nation under stress for years exercised the right to vote. The election offered a democratic system of governance and essentially is an opportunity for all Afghans to ensure their contribution in development of their country.

More than a million Afghan refugees reside in the NWFP (North-Western Frontier Province) of Pakistan. A large number of refugee population dwells in camps scattered all around the province. These refugees were initially registered by the Commissionarate of Afghan Refugees, (CAR), which was setup after the refugees started to pour into Pakistan after the Soviet invasion. However, emergency situation led to mass exodus from and to these camps and many refugees, in search of better lives, migrated to the urban areas of the province. Organizing election for them in these circumstances was always a challenge. According to the CAR, there were around 0.8 million eligible refugee voters in camps and urban areas in NWFP alone. However, there were cases where many refugees, having identification documents, had moved to other areas in the province. Tracing, registering, organizing the election and voting facilities close to their homes required a well-defined strategy.

The International Organization for Migration, (IOM) and BEFARe teamed-up to initiate this challenging process. The process involved recruitment of 400 Community Mobilizers for IOM, majority of whom were Afghans from refugee camps and urban areas in proximity to refugee population. More than 1,500 individuals, largely from Afghan community, were interviewd and the Community Mobilizers were deputed to their duty stations in Peshawar, Abbottabad, Mardan, Timergara, Bannu and Hangu. All BEFARe sub-offices located in these areas coordinated activities at that level.

Later, more than 6,600 registration and polling staff recruited for duties at polling stations in the election were trained by BEFARe. BEFARe, apart from training the Community Mobilizers and provision of voters education to the community, also provided logistical support for public gatherings in camps and during the elections. Around 300 public gathering as a part of mass awareness campaigns, were organized in Mardan, Timergara, Abbottabad, Bannu, Kohat and Peshawar and in the rest of NWFP.

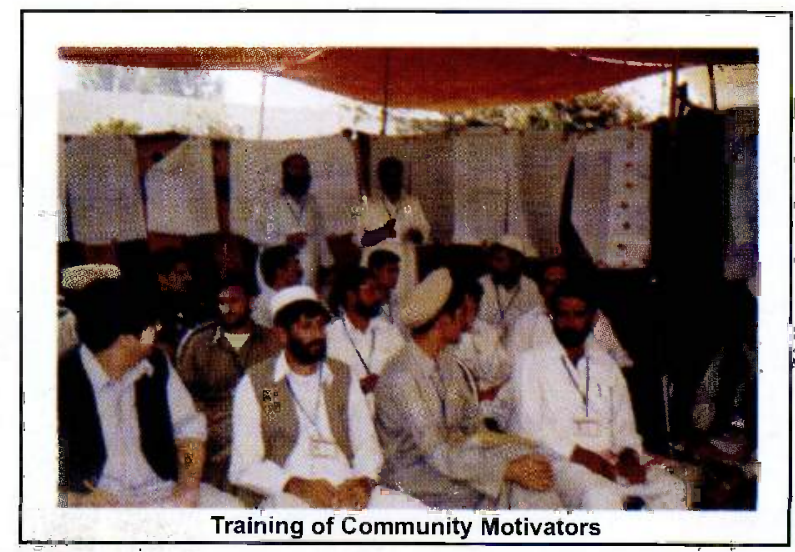




\begin{tabular}{|l|c|c|c|}
\hline \multirow{2}{*}{ Sub-Office } & & \multicolumn{2}{|c|}{ Public Gatherings Held } \\
\cline { 3 - 4 } & Total & Male & Female \\
\hline Mardan & 42 & 21 & 21 \\
\hline Timergara & 50 & 25 & 25 \\
\hline Abbottabad & 32 & 6 & 16 \\
\hline Bannu & 24 & 11 & 11 \\
\hline Hangu & 76 & 38 & 38 \\
\hline Peshawar & 76 & $\mathbf{3 9}$ & 36 \\
\hline Total & $\mathbf{3 0 0}$ & $\mathbf{1 5 0}$ & $\mathbf{1 4 7}$ \\
\hline Detail of public gatherings facilitated by BEFARe throughout NWF P \\
\hline
\end{tabular}

The mass awareness campaigns helped a lot, as despite some threats, the Afghan community, shunning their fears, participated in large numbers. More than four hundred
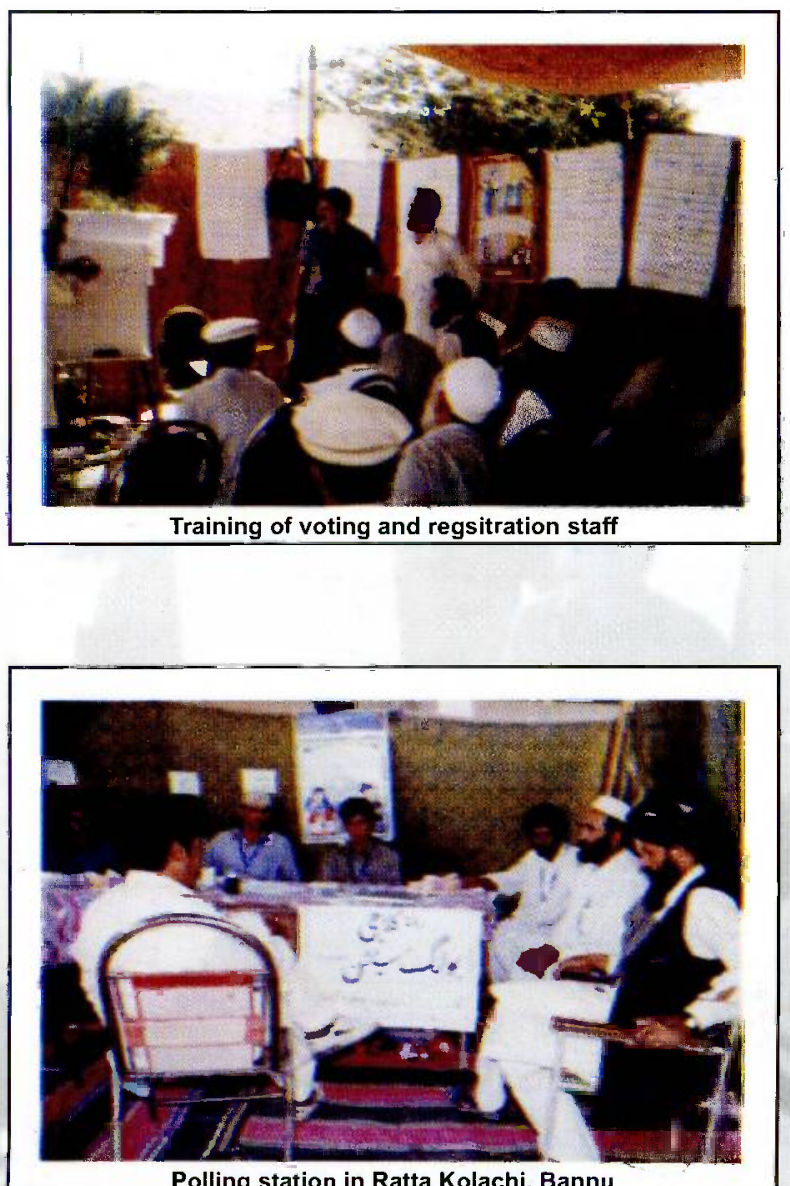

Polling station in Ratta Kolachi, Bannu thousand Afghans voted in the NWFP alone. The initiative enabled all displaced Afghan refugees in NWFP, Pakistan to have their say in the future of their country.

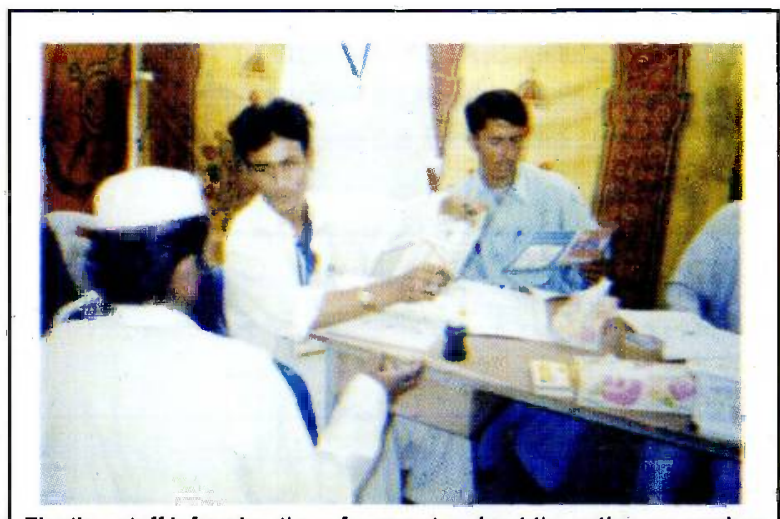

Election staff informing the refugee voter about the voting proceedure

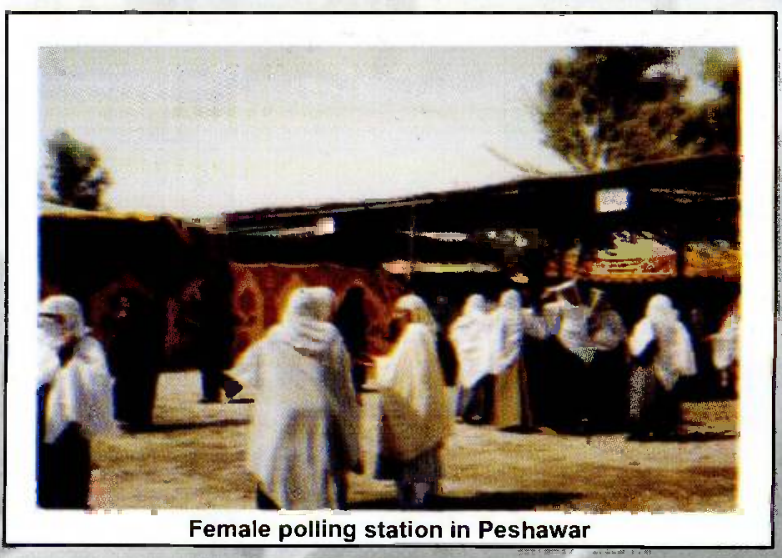


BEFARe also facilitated IOM with logistical support in registration of voters and establishment of registration and polling stations throughout the province. The sites for establishment of registration and polling stations were identified after conducting an extensive field survey by BEFARe. Later, more than 1,000 registration and polling stations were established all over the NWFP.

\section{The detailed information of all those registration}

and polling stations is represented below:

\begin{tabular}{|c|l|c|}
\hline S.No. & \multicolumn{1}{|c|}{ Area } & $\begin{array}{c}\text { Number of Polling } \\
\text { Stations }\end{array}$ \\
\hline 1 & Abbottabad & 140 \\
\hline 2 & Bannu & 28 \\
\hline 3 & Peshawar & 436 \\
\hline 4 & Hangu & 192 \\
\hline 5 & Mardan & 120 \\
\hline 6 & Timergara & 88 \\
\hline & & $\mathbf{1 , 0 0 4}$ \\
\hline
\end{tabular}

In each geographical location half of the registration and polling stations were reserved for females. BEFARe provided all the required facilities and equipment necessary for the establishment of R\&P stations.

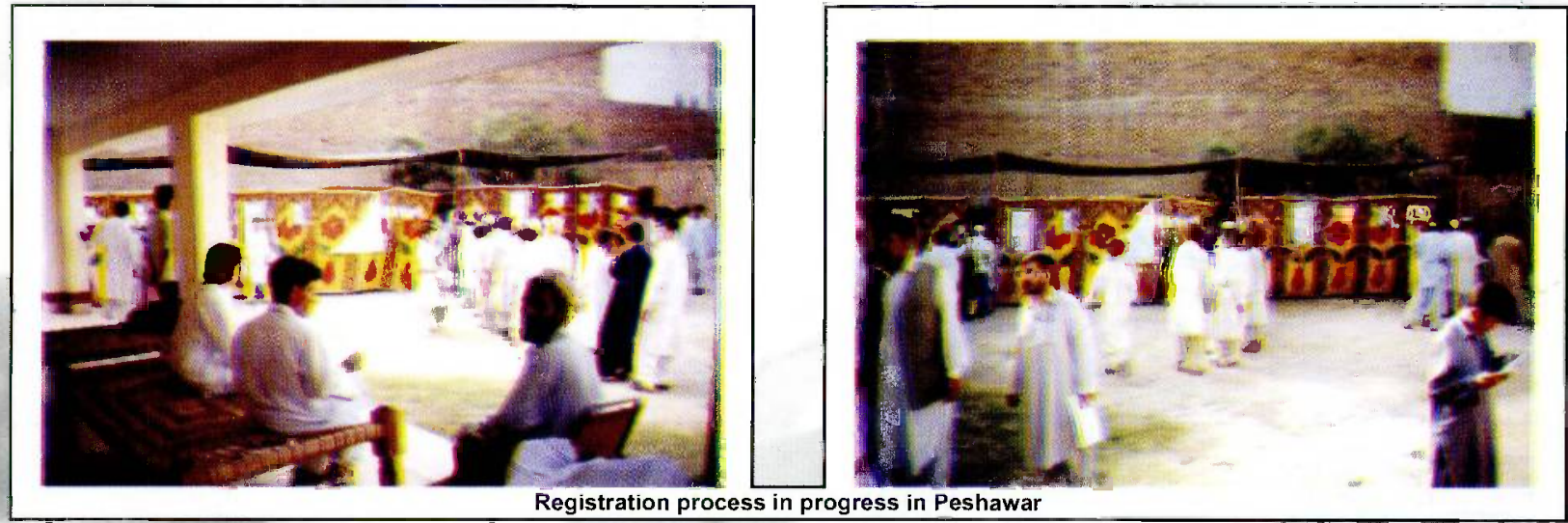




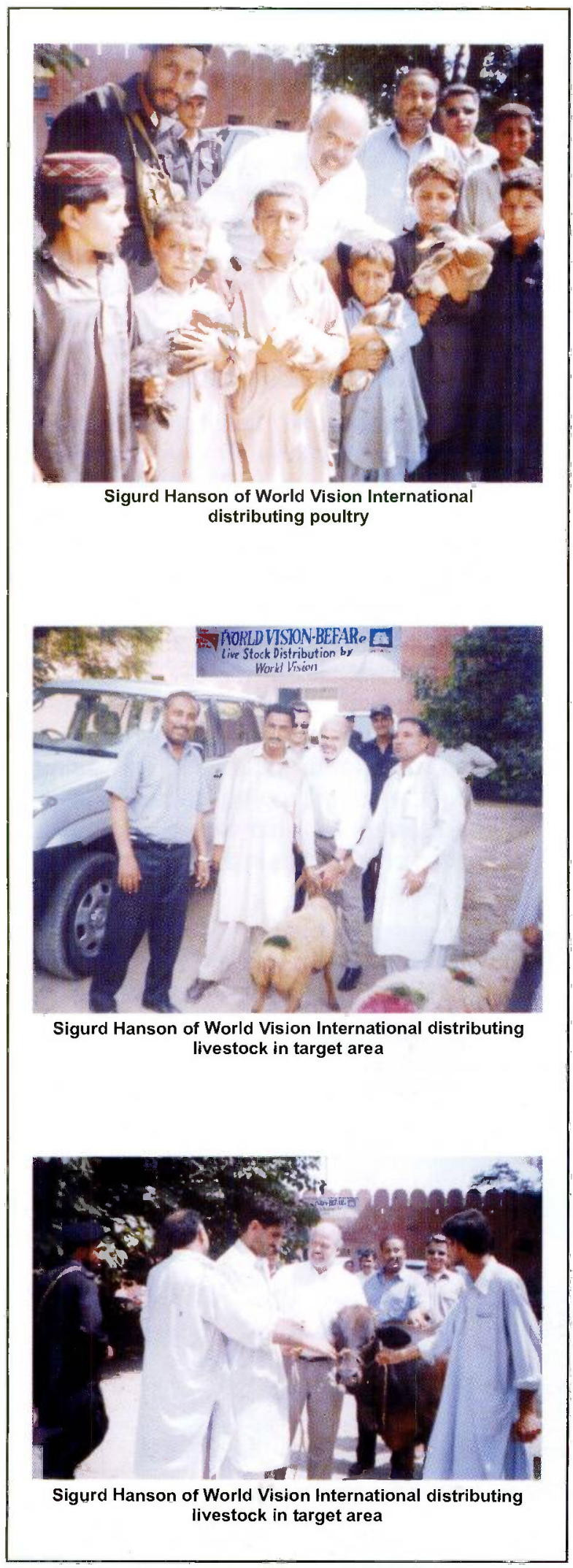

\section{Poverty Alleviation Initiatives Supported by World Vision}

Working in a wide geographical area throughout the NWFP, BEFARe is cognizant of many areas where specific and innovative poverty alleviation interventions are required. Many poverty alleviation plans such as initiation of vocational skills training leading to establishment of small enterprises has been implemented quite often. As mitigating poverty requires a wide and innovative array of interventions, BEFARe strives to look for partner willing to facilitate such support.

In 2004, BEFARe signed a contract to facilitate World Vision Pakistan in distribution of livestock in identified underprivileged communities in Utmanzi village for local farmers and in Barakai refugee camps for Afghan refugee children. The basic theme in livestock distribution was to help farmers and identified rural communities utilize the support in farming and agriculture. In this context, fifteen quality hybrid bulls, 88 sheep, 2,505 pairs of rabbits and 2,587 pairs of ducks were distributed among most needy individuals. The project was aimed at poverty alleviation through self sustained initiatives.

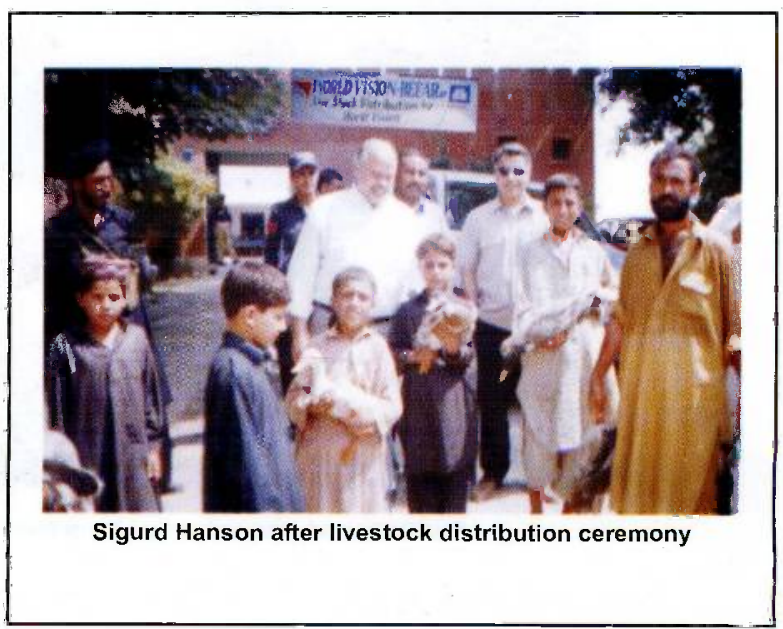




\section{SEMINARS AND WORKSHOPS}

- As an organization engaged in education in emergency situations, BEFARe continuously looks for opportunities to share and upgrade its quality standards in education. In this context, Mr. Shakir Ishaq, the Chief Executive, represented BEFARe at Regional Consultations of Inter Agency Network for Education in Emergencies (INEE), for the development of minimum standards for Emergency Education held at Kathmandu, Nepal and subsequently Global Consultations held at Cape Town, South Africa. These consultations aimed to share experiences and develop minimum standards for education in emergencies, chronic crisis and early reconstruction. BEFARe sees its participation in the consultation as a step towards improvement in Emergency Education quality standards.

- Dr. Michael Gruener from GTZ visited BEFARe for a workshop on improving management and implementation of activities. At the end of various brain storming sessions with the management team the consultant proposed some
- initiatives for implementing a Quality Management System at BEFARe.

- As a part of the transformation process from a bilateral project to an independent entity, an organizational development \& team building workshop, facilitated by $\mathbf{M r}$. Mehmood Hemani, was organized to assist the process of CHANGE. The workshop facilitated management team on organizational development, potential problems and future strategies.

- Dr. S.B Ekanayake facilitated Alternative Field and Institutional Training" (AFIT) of Sub-Office Managers. BEFARe has suboffices located in Hangu, Bannu, Abbottabad, Timergara and Mardan. Keeping inline with the requirements and activities, the Sub- Office Managers were imparted training on educational issues, management leading to educational development, resource mobilization, human relations and linkages, and capacity to face emergency situations. The training, in addition to improving capacity of suboffice managers, also improved the data reporting procedures in the sub-offices.

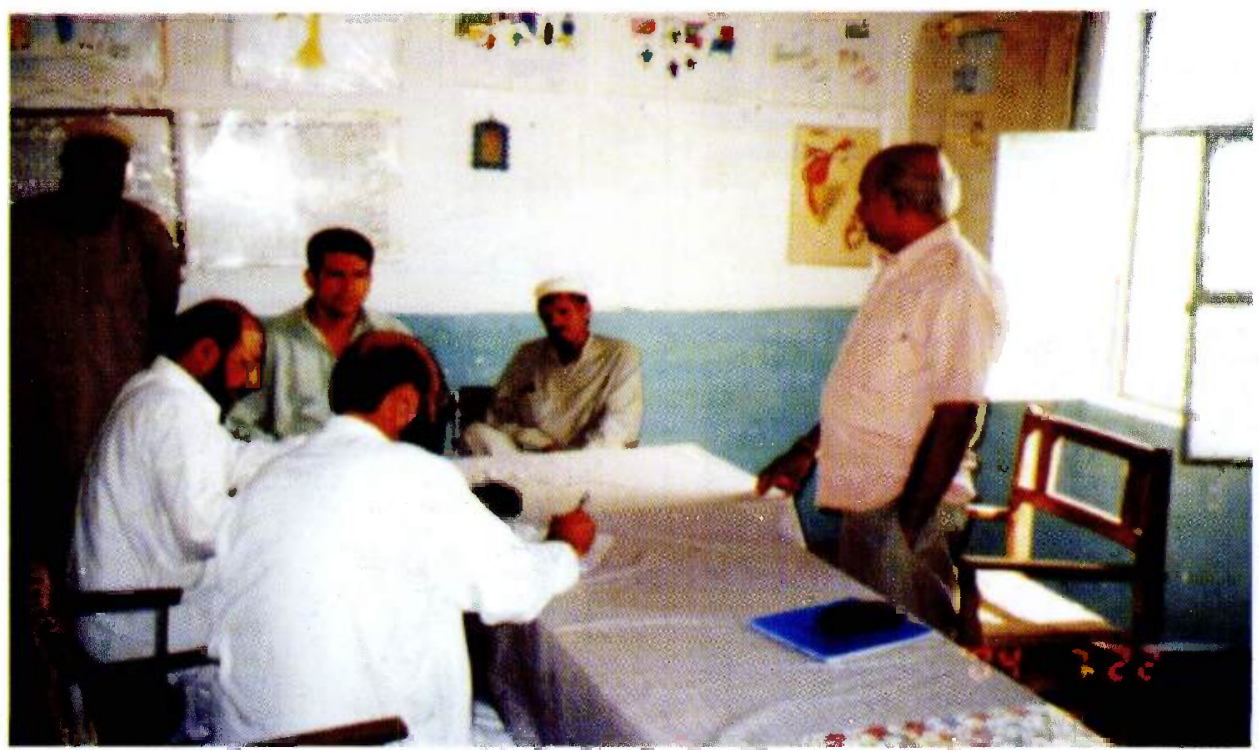

Facilitation of Alternative Field and Institutional Training (AFIT) of Sub-Office Managers 
- As BEFARe administers concepts such as human rights, female education, health, environment, conflict resolution and peace education; it also looks for ways to develop and create awareness about these concepts. BEFARe co-hosted a seminar on peace education with Mr. Sayyed Jonaid Shah representing BEFARe, Mr. Atle Hetland and PACADE, Lahore. Ms. Pamela Baxter, Peace Education Cocoordinator with UNHCR and Senior Technical Advisor in Peace and Human Rights in UNESCO were the keynote speakers.

- BEFARe also participated in a workshop on
- gender disparities. Organized by the Textbook Board, NWFP with the objective to review the textbooks offered at various school levels in the NWFP and identify the concepts in relation to gender disparities and discuss ways to mitigate the problem. A select group of educationalist and scholars were invited from various organizations. BEFARe was represented by Dr. Mehmooda Rehman in the workshop. She presented her findings on the subject matter for science in various grades. The effort will lead to eliminating gender disparities in curriculum taught in various grades in the province.

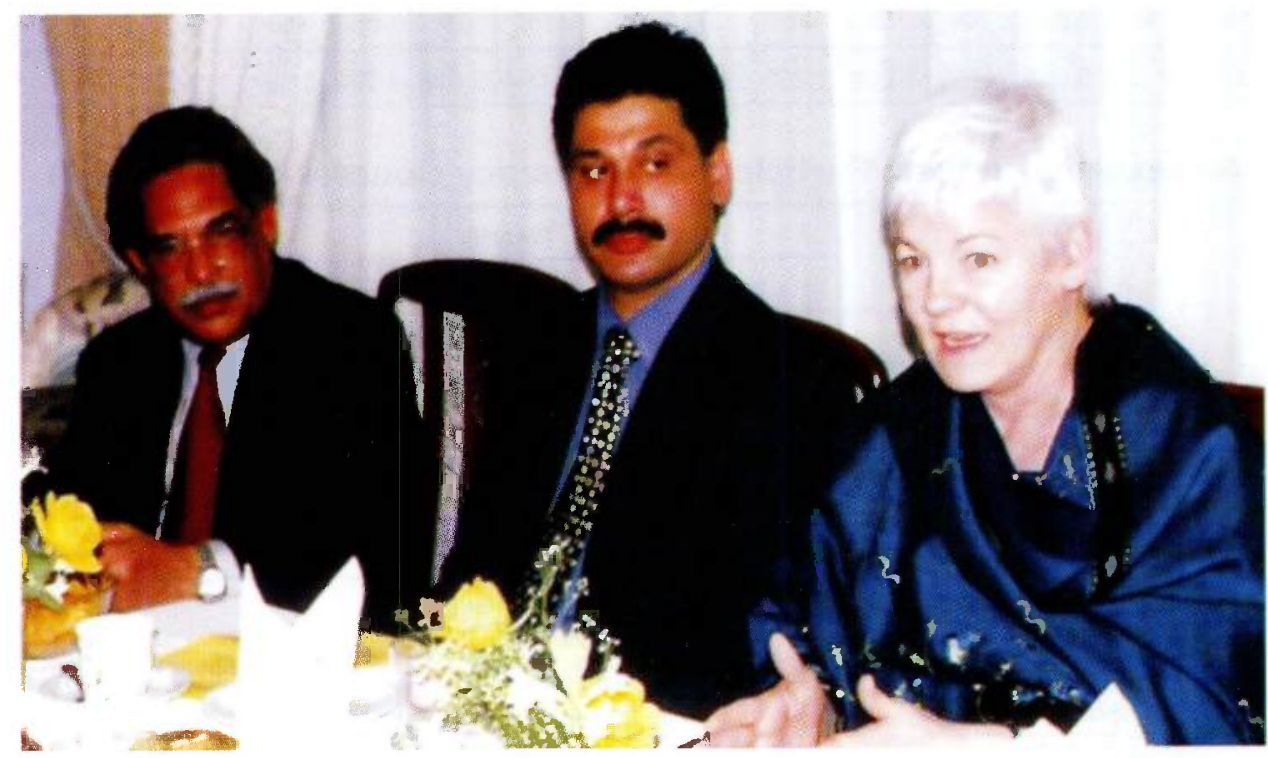

Seminar on Peace Education co-hosted by BEFARe 


\section{LIST OF ANNEXURES}

Annexure 1: Recollection of Pashto, Mathematics and Urdu books

\begin{tabular}{|c|c|c|c|c|c|c|c|c|c|c|c|c|c|}
\hline \multirow{2}{*}{ Sub-Offices } & \multicolumn{4}{|c|}{ Pashto Books } & \multicolumn{4}{|c|}{ Math Books } & \multicolumn{5}{|c|}{ Urdu Books } \\
\hline & G-III & G-IV & G-V & G-VI & G-III & G-IV & G-V & G-VI & G-II & G-III & G-IV & G-V & G-VI \\
\hline Timergara & 828 & 538 & 499 & 476 & 648 & 487 & 494 & 524 & 354 & 381 & 455 & 348 & 331 \\
\hline Hangu & 805 & 633 & 677 & 497 & 565 & 382 & 422 & 309 & 588 & 548 & 491 & 446 & 353 \\
\hline Peshawar & 1895 & 1219 & 976 & 757 & 969 & 968 & 912 & 670 & 995 & 847 & 984 & 622 & 608 \\
\hline Bannu & 522 & 421 & 336 & 242 & 441 & 369 & 324 & 344 & 593 & 494 & 398 & 272 & 199 \\
\hline Mardan & 533 & 370 & 300 & 310 & 242 & 330 & 256 & 310 & 300 & 270 & 325 & 255 & 310 \\
\hline Abbottabad & 113 & 50 & 64 & 50 & 136 & 43 & 32 & 31 & 39 & 41 & 42 & 52 & 32 \\
\hline Total & 4,696 & 3,231 & 2,852 & 2,332 & 3,001 & 2,579 & 2,440 & 2,188 & 2,869 & 2,581 & 2,695 & 1,995 & 1,833 \\
\hline
\end{tabular}

Annexure 2:Recollection of Islamiat, English, Science and Social Study books

\begin{tabular}{|c|c|c|c|c|c|c|c|c|c|c|c|c|c|c|c|c|c|}
\hline \multirow{2}{*}{ Sub-Offices } & \multicolumn{6}{|c|}{ Islamiat Books } & \multicolumn{5}{|c|}{ English Books } & \multicolumn{3}{|c|}{ Science Books } & \multicolumn{3}{|c|}{$\begin{array}{c}\text { Social Study } \\
\text { Books }\end{array}$} \\
\hline & $\overline{0}$ & $\overline{1}$ & 三 & $\geq_{0}$ & 3 & 交 & $\overline{\bar{\sigma}}$ & $\overline{\bar{b}}$ & \} $&{\frac{7}{6}} &{\frac{5}{6}} &{\text { \' }} &{3} &{\text { ड़ }} &{\frac{2}{0}} &{\text { S }} &{\text { 交 }} \\
{\hline \text { Tim }} &{590} &{730} &{1041} &{864} &{707} &{507} &{339} &{348} &{390} &{336} &{338} &{762} &{827} &{536} &{1431} &{\uparrow 126} &{836} \\
{\hline \text { Hangu }} &{727} &{732} &{980} &{643} &{560} &{245} &{424} &{507} &{480} &{401} &{282} &{681} &{556} &{517} &{1214} &{1150} &{799} \\
{\hline \text { Peshawar }} &{2306} &{2032} &{2090} &{1588} &{1106} &{1048} &{1139^{\circ}} &{1984} &{636} &{697} &{605} &{1420} &{1173} &{946} &{2624} &{2155^{\prime}} &{1879} \\
{\hline \text { Bannu }} &{825} &{907} &{719} &{510} &{371} &{262} &{505} &{458} &{387} &{239} &{214} &{462} &{361} &{235} &{288} &{198^{\circ}} &{206} \\
{\hline \text { Mardan }} &{450} &{625} &{670} &{390} &{385} &{130} &{230} &{156} &{225} &{356} &{265} &{530} &{415} &{160} &{760} &{695} &{295} \\
{\hline \text { Abbottabad }} &{121} &{95} &{65} &{108} &{73} &{68} &{30} &{37} &{76} &{29} &{35} &{69} &{35} &{43} &{65} &{47} &{33} \\
{\hline \text { Total }} &{019} &{5,121} &{5,565} &{4,103} &{3,202} &{2,260} &{2,667} &{3,490} &{2,194} &{2,058} &{1,739} &{3,924} &{3,367} &{2,437} &{6,382} &{5,371} &{4,04} \\
$\hline
\end{tabular}

Annexure 3: Female Participants in Literacy Courses (CIDAAREP)

\begin{tabular}{|c|c|c|}
\hline \multirow{2}{*}{ Sub-Offices } & \multicolumn{2}{|c|}{ Reader } \\
\cline { 2 - 3 } & Courses & Participants \\
\hline Abbotabad & 2 & 49 \\
\hline Timergara & 1 & 24 \\
\hline Total & 3 & 73 \\
\hline
\end{tabular}

Annexure 4: Male Participants in Literacy Courses (CIDA/AREP)

\begin{tabular}{|l|c|c|}
\hline \multirow{2}{*}{ Sub-Offices } & \multicolumn{2}{|c|}{ Reader } \\
\cline { 2 - 3 } & Courses & Participants \\
\hline Abbottabad & 3 & 50 \\
\hline Peshawar & 2 & 30 \\
\hline Timergara & 8 & 272 \\
\hline Hangu & 4 & 57 \\
\hline Mardan $\quad$ Total & - & 0 \\
\hline \multicolumn{1}{|c|}{$\quad 17$} & $\mathbf{4 0 9}$ \\
\hline
\end{tabular}


Annexure 5: Home Schools for Girls (CIDA/AREP)

\begin{tabular}{|l|c|c|c|c|c|c|}
\hline \multirow{2}{*}{ Sub-Offices } & \multicolumn{2}{|c|}{ Grade - III } & \multicolumn{2}{c|}{ Grade - IV } & \multicolumn{2}{c|}{ Grade -V } \\
\cline { 2 - 7 } & Courses & Participants & Courses & Participants & Courses & Participants \\
\hline Abbottabad & 1 & 21 & 10 & 208 & 18 & 335 \\
\hline Timergara & 4 & 97 & 3 & 82 & 22 & 471 \\
\hline Peshawar & 4 & 107 & 22 & 509 & 18 & 400 \\
\hline Hangu & 0 & 0 & 0 & 0 & 1 & 25 \\
\hline \multicolumn{1}{|c|}{ Total } & $\mathbf{9}$ & $\mathbf{2 2 5}$ & $\mathbf{3 5}$ & $\mathbf{7 9 9}$ & $\mathbf{5 9}$ & $\mathbf{1 2 3 1}$ \\
\hline
\end{tabular}

Annexure 6: Home Schools for Boys (CIDA/AREP)

\begin{tabular}{|l|c|c|c|c|c|c|}
\hline \multirow{2}{*}{ Sub-offices } & \multicolumn{2}{|c|}{ Grade - III } & \multicolumn{2}{c|}{ Grade - IV } & \multicolumn{2}{c|}{ Grade -V } \\
\cline { 2 - 8 } & Courses & Participants & Courses & Participants & Courses & Participants \\
\hline Abbottabad & 1 & 23 & 1 & 24 & 8 & 192 \\
\hline Peshawar & 6 & $\mathbf{1 4 5}$ & 6 & 134 & 0 & 0 \\
\hline Timergara & 0 & 0 & 0 & 0 & 18 & 450 \\
\hline Hangu & 0 & 0 & 2 & 55 & 1 & 30 \\
\hline \multicolumn{1}{|c|}{ Total } & $\mathbf{7}$ & $\mathbf{1 6 8}$ & $\mathbf{9}$ & $\mathbf{2 1 3}$ & $\mathbf{2 7}$ & $\mathbf{6 7 2}$ \\
\hline
\end{tabular}

Annexure 7: Home Schools Co-education Courses (CIDA/AREP)

\begin{tabular}{|l|c|c|c|c|c|c|c|c|c|}
\hline \multirow{2}{*}{ Sub-Offices } & \multicolumn{4}{|c|}{ Grade-III } & \multicolumn{3}{c|}{ Grade-IV } & \multicolumn{3}{c|}{ Grade-V } \\
\cline { 2 - 12 } & Courses & Boys & Girls & Courses & Boys & Girls & Courses & Boys & Girls \\
\hline Abbottabad & 1 & 24 & 6 & 1 & 18 & 17 & 2 & 31 & 12 \\
\hline Peshawar & 7 & 117 & 84 & 5 & 92 & 49 & & 0 & 0 \\
\hline Hangu & 0 & 0 & 0 & 4 & 55 & 45 & 11 & 115 & 178 \\
\hline Timergara & 0 & 0 & 0 & 0 & 0 & 0 & 2 & 28 & 9 \\
\hline \multicolumn{1}{|c|}{ Total } & $\mathbf{8}$ & $\mathbf{1 4 1}$ & $\mathbf{9 0}$ & $\mathbf{1 0}$ & $\mathbf{1 6 5}$ & $\mathbf{1 1 1}$ & $\mathbf{1 5}$ & $\mathbf{1 7 4}$ & $\mathbf{1 9 9}$ \\
\hline
\end{tabular}

Annexure 8: Trade wise Female Vocational Skill Training Centers and Participants

\begin{tabular}{|c|c|c|c|c|c|c|c|c|}
\hline \multirow{2}{*}{ Sub-Offices } & \multicolumn{2}{|c|}{ Tailoring } & \multicolumn{2}{c|}{ Embroidery } & \multicolumn{2}{c|}{ Beads Making } & \multicolumn{2}{c|}{ Total } \\
\cline { 2 - 10 } & $\begin{array}{c}\mathbf{V T} \\
\text { Centers }\end{array}$ & Participants & $\begin{array}{c}\text { VT } \\
\text { Centers }\end{array}$ & Participants & $\begin{array}{c}\text { VT } \\
\text { Centers }\end{array}$ & Participants & $\begin{array}{c}\text { VT } \\
\text { Centers }\end{array}$ & Participants \\
\hline Peshawar & 3 & 30 & 1 & 10 & 2 & 50 & 6 & 90 \\
\hline Timergara & 3 & 30 & 1 & 10 & 1 & 20 & 5 & 50 \\
\hline Abbottabad & 2 & 20 & 2 & 20 & & & 4 & 40 \\
\hline Mardan & 5 & 25 & & & & & 5 & 25 \\
\hline Total & $\mathbf{1 3}$ & $\mathbf{1 0 5}$ & $\mathbf{4}$ & $\mathbf{4 0}$ & $\mathbf{3}$ & $\mathbf{7 0}$ & $\mathbf{2 0}$ & $\mathbf{2 0 5}$ \\
\hline
\end{tabular}


Annexure 9: Trade wise Male Vocational Skill Training Centers and Participants

\begin{tabular}{|l|c|c|c|c|c|c|c|c|}
\hline \multirow{2}{*}{ Sub-Offices } & \multicolumn{2}{|c|}{ Tailoring } & \multicolumn{2}{c|}{ Carpentry } & \multicolumn{2}{c|}{ Bicycle repair } & \multicolumn{2}{c|}{ Total } \\
\cline { 2 - 9 } & $\begin{array}{c}\mathbf{V} \\
\text { Centers }\end{array}$ & Participants & $\begin{array}{c}\text { VT } \\
\text { Centers }\end{array}$ & Participants & $\begin{array}{c}\text { VT } \\
\text { Centers }\end{array}$ & Participants & $\begin{array}{c}\text { VT } \\
\text { Centers }\end{array}$ & Participants \\
\hline Peshawar & 2 & 20 & & & & & 2 & 20 \\
\hline Timergara & 1 & 10 & 2 & 20 & & & 3 & 30 \\
\hline Abbottabad & 1 & 10 & 1 & 10 & 1 & 10 & 3 & 30 \\
\hline Hangu & 1 & 10 & 1 & 5 & & & 2 & 15 \\
\hline \multicolumn{1}{|c|}{ Total } & $\mathbf{5}$ & $\mathbf{5 0}$ & 4 & $\mathbf{3 5}$ & $\mathbf{1}$ & $\mathbf{1 0}$ & $\mathbf{1 0}$ & $\mathbf{9 5}$ \\
\hline
\end{tabular}

\section{Annexure 10: Field-Office wise Fund Raising during Different Periods}

\begin{tabular}{|l|c|c|c|c|}
\hline \multirow{2}{*}{ Sub-Offices } & \multicolumn{2}{|c|}{ Year 2004 } & \multicolumn{2}{c|}{$1996-\mathbf{2 0 0 3}$} \\
\cline { 2 - 5 } & $\begin{array}{c}\text { No. of } \\
\text { schools }\end{array}$ & $\begin{array}{c}\text { Fund raised } \\
\text { in Rs. }\end{array}$ & $\begin{array}{c}\text { No. of } \\
\text { schools }\end{array}$ & $\begin{array}{c}\text { Fund raised } \\
\text { in Rs. }\end{array}$ \\
\hline Abbottabad & 33 & 427,309 & 35 & $1,274,526$ \\
\hline Bannu & 33 & 143,507 & 40 & 681,588 \\
\hline Peshawar & 48 & $1,103,824$ & 53 & $3,277,488$ \\
\hline Mardan & 35 & 494,145 & 35 & $1,414,706$ \\
\hline Hangu & 42 & 525,278 & 44 & $1,910,894$ \\
\hline Timergara & 37 & 218,560 & 37 & 938,272 \\
\hline Female & 73 & 502,428 & 76 & $1,930,609$ \\
\hline \multicolumn{1}{|c|}{ Total } & 301 & $3,415,051$ & 320 & $11,428,083$ \\
\hline
\end{tabular}

Annexure 11: Input of Community in Construction Activities during the Year 2004

\begin{tabular}{|l|c|c|c|c|c|c|c|c|c|}
\hline \multirow{2}{*}{ Sub-Offices } & \multicolumn{2}{|c|}{ Class rooms constructed } & \multicolumn{3}{c|}{ Verandas constructed } & \multicolumn{3}{c|}{ Toilets constructed } \\
\cline { 2 - 10 } & Schools & $\begin{array}{c}\text { No. of } \\
\text { rooms }\end{array}$ & $\begin{array}{c}\text { Amount } \\
\text { spent in } \\
\text { Rs }\end{array}$ & Schools & $\begin{array}{c}\text { No. of } \\
\text { verandas I } \\
\text { wooden shed }\end{array}$ & $\begin{array}{c}\text { Amount } \\
\text { spent in } \\
\text { Rs. }\end{array}$ & $\begin{array}{c}\text { No. of } \\
\text { Schools }\end{array}$ & $\begin{array}{c}\text { No. of } \\
\text { Toilets }\end{array}$ & $\begin{array}{c}\text { Amount } \\
\text { spent in } \\
\text { Rs. }\end{array}$ \\
\hline Abbottabad & 3 & 3 & 26,700 & 2 & $1 / 1$ & 1,500 & 9 & 13 & 19,098 \\
\hline Peshawar & 8 & 20 & 218,472 & 10 & $3 / 13$ & 31,370 & 3 & 4 & 6,030 \\
\hline Mardan & 8 & 14 & 117,294 & 4 & $4 / 0$ & 17,148 & 3 & 3 & 7,857 \\
\hline Hangu & 0 & 0 & 0 & 5 & $0 / 9$ & 2,894 & 1 & 1 & 2,610 \\
\hline Timergara & 0 & 0 & 0 & 2 & $0 / 2$ & 1,145 & 0 & 0 & 0 \\
\hline Female & 1 & 1 & 2,200 & 2 & $2 / 0$ & 1,842 & 1 & 2 & 2,500 \\
\hline \multicolumn{1}{|c|}{ Total } & $\mathbf{2 0}$ & $\mathbf{3 8}$ & $\mathbf{3 6 4 , 6 6 6}$ & $\mathbf{2 5}$ & $\mathbf{1 0 / 2 5}$ & $\mathbf{5 5 , 8 9 9}$ & $\mathbf{1 7}$ & $\mathbf{2 3}$ & $\mathbf{3 8 , 0 9 5}$ \\
\hline
\end{tabular}


Annexure 12: Improvement of Infrastructure carried out during Year 2004

\begin{tabular}{|l|c|c|c|c|c|c|c|c|c|c|}
\hline & \multicolumn{3}{|c|}{ Roof replacement } & \multicolumn{2}{c|}{ Boundary wall construction } & \multicolumn{3}{c|}{ Shallow well digging and further } \\
digging
\end{tabular}

Annexure 13: Annual Days Celebrated in Various Schools

\begin{tabular}{|l|c|c|c|c|}
\hline \multirow{2}{*}{ Sub-Offices } & \multicolumn{4}{|c|}{ Annual Days } \\
\cline { 2 - 5 } & $\begin{array}{c}\text { No. of schools } \\
\text { celebrated } \\
\text { annual days }\end{array}$ & $\begin{array}{c}\text { No. of } \\
\text { students } \\
\text { took part }\end{array}$ & $\begin{array}{c}\text { Parents } \\
\text { participated }\end{array}$ & $\begin{array}{c}\text { Amount } \\
\text { Spent in Rs. }\end{array}$ \\
\hline Abbottabad & 15 & 251 & 300 & 1807 \\
\hline Bannu & 31 & 279 & 465 & 3204 \\
\hline Peshawar & 40 & 320 & 880 & 6144 \\
\hline Mardan & 29 & 522 & 1160 & 2410 \\
\hline Hangu & 39 & 363 & 1092 & 8970 \\
\hline Timergara & 30 & 410 & 1110 & N. Books \\
\hline Female & 66 & 860 & 918 & 9698 \\
\hline \multicolumn{1}{|c|}{ Total } & $\mathbf{2 5 0}$ & $\mathbf{3 , 0 0 5}$ & $\mathbf{5 , 9 2 5}$ & $\mathbf{3 2 , 2 6 3}$ \\
\hline
\end{tabular}

Annexure 14: Parent's Day / Debates Organized in Various Schools

\begin{tabular}{|l|c|c|c|c|c|}
\hline \multirow{2}{*}{ Sub-Offices } & \multicolumn{5}{|c|}{ Parent's day/ debates organized } \\
\cline { 2 - 6 } & $\begin{array}{c}\text { No. of } \\
\text { Parents days }\end{array}$ & $\begin{array}{c}\text { No. of } \\
\text { debates }\end{array}$ & $\begin{array}{c}\text { Students } \\
\text { participated }\end{array}$ & $\begin{array}{c}\text { Parents/community } \\
\text { members }\end{array}$ & $\begin{array}{c}\text { Expenses } \\
\text { (Rs) }\end{array}$ \\
\hline Abbottabad & 0 & 0 & 0 & 0 & 0 \\
\hline Bannu & 8 & 8 & 92 & 296 & 2658 \\
\hline Peshawar & 8 & 8 & 230 & 1100 & 6140 \\
\hline Mardan & 8 & 8 & 102 & 715 & 3000 \\
\hline Hangu & 23 & 23 & 388 & 763 & 19711 \\
\hline Timergara & 8 & 8 & 210 & 350 & 4600 \\
\hline Female & 13 & 13 & 215 & 310 & 3370 \\
\hline \multicolumn{1}{|c|}{ Total } & $\mathbf{6 8}$ & $\mathbf{6 8}$ & $\mathbf{1 , 2 3 7}$ & $\mathbf{3 , 5 3 4}$ & $\mathbf{3 9 , 4 7 9}$ \\
\hline
\end{tabular}


Annexure 15: Sports Competitions held in Various Schools

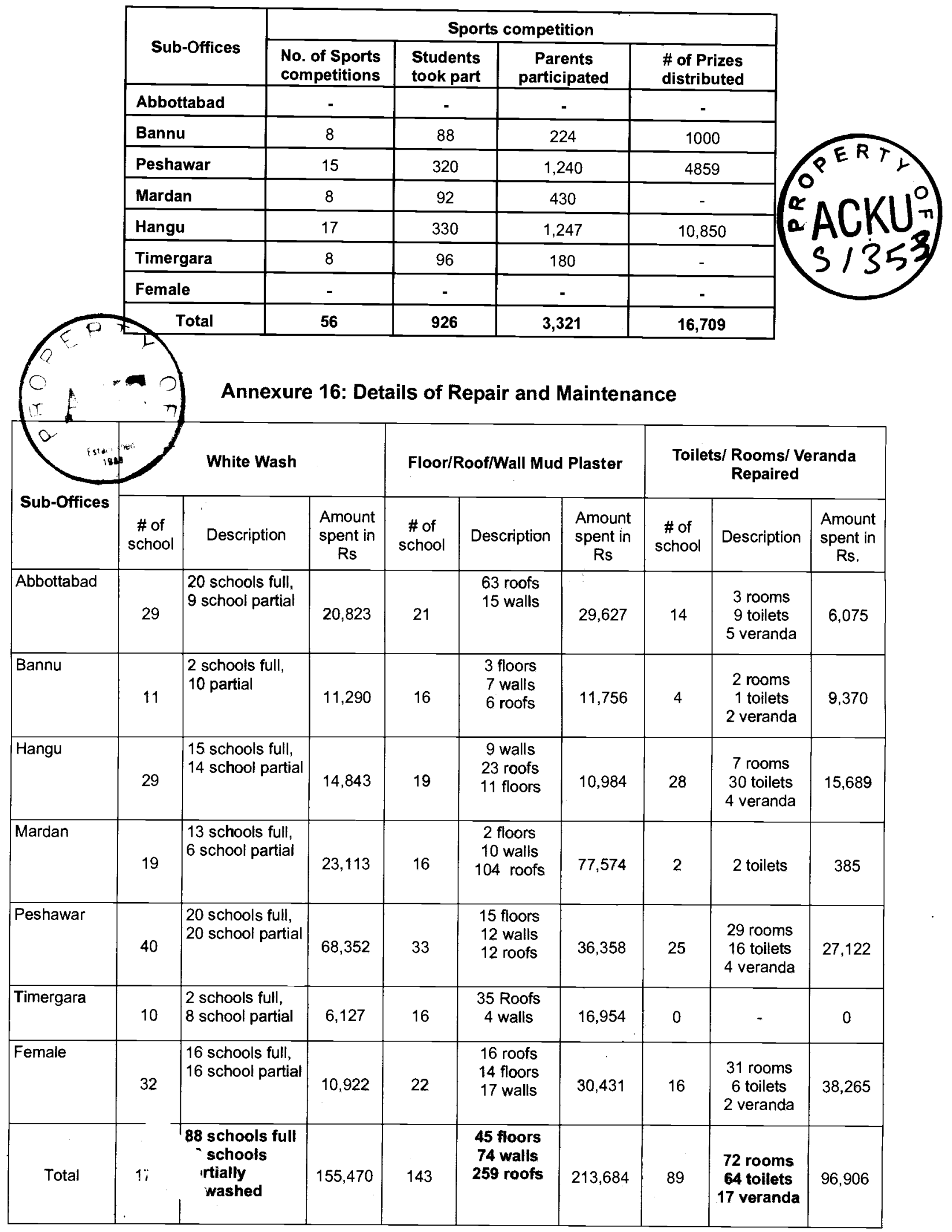




\section{BEFARe}

Head Office : 8 - Tatara Road, Rahatabad,Peshawar.

\section{Contact : : 92-91-5840631, 5702955}

Fax : 92-91-5841047

Email : befare@befare.org, befare@brain.net.pk

Website : www.befare.org 